Electronic Supplementary Information for

\title{
Iron(III) Nitrate/TEMPO-Catalyzed Aerobic Alcohol Oxidation: Distinguishing between Serial versus Integrated Redox Cooperativity
}

\author{
Jordan E. Nutting, Kaining Mao, Shannon S. Stahl* \\ Department of Chemistry, University of Wisconsin-Madison, 1101 University Avenue, \\ Madison, Wisconsin 53706, United States \\ stahl@chem.wisc.edu
}

\section{Table of Contents}

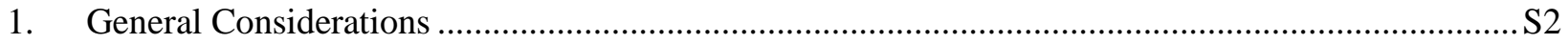

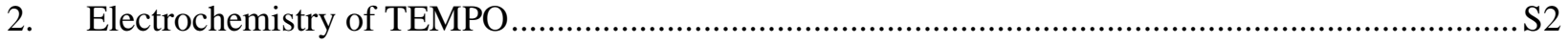

3. Cyclic Step Chronoamperometry-Rotating Disk Electrode Experiments ....................................S2

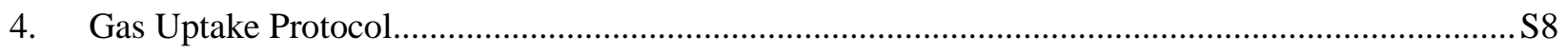

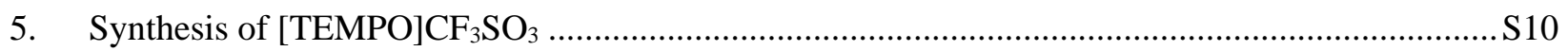

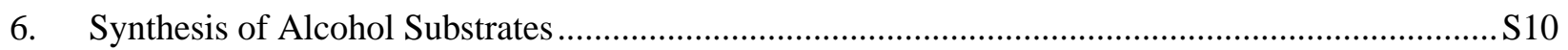

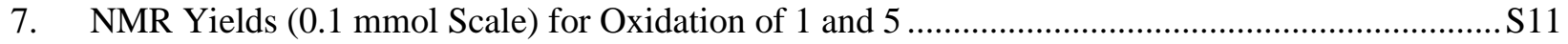

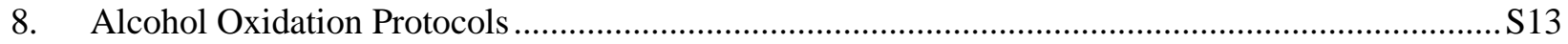

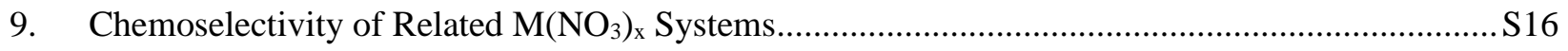

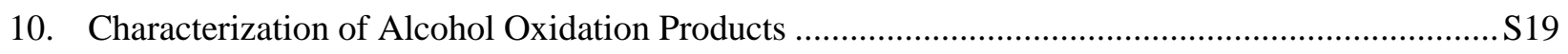

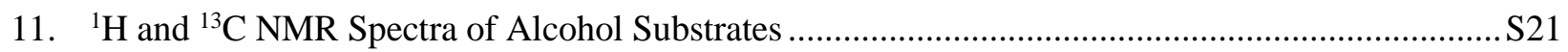

12. $\quad{ }^{1} \mathrm{H}$ and ${ }^{13} \mathrm{C}$ NMR Spectra of Alcohol Oxidation Products.............................................................S24

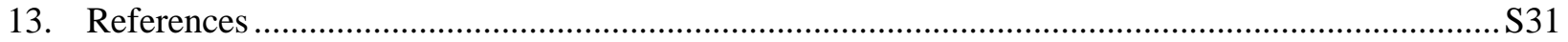




\section{General Considerations}

\section{Reagents:}

Unless noted, all commercial chemicals and solvents were purchased from Millipore-Sigma and were used without further purification. $\mathrm{Fe}(\mathrm{OTf})_{3}$ was purchased from Combi-Blocks. Acetonitrile was obtained from an LC Technology Solutions Inc. solvent purification system.

\section{Instruments and Techniques:}

${ }^{1} \mathrm{H}$ and ${ }^{13} \mathrm{C}$ NMR spectra were recorded on Bruker Avance III 400 and Bruker Avance III 500 spectrometers. Chemical shifts are given in parts per million ( $\mathrm{ppm}$ ) relative to residual solvent peaks. Gas chromatographs were collected on a Shimadzu GC-2010 Gas Chromatograph. High-resolution mass spectra were obtained using a Thermo Q ExactiveTM Plus by the mass spectrometry facility at the University of WisconsinMadison. Chromatographic purification of products was accomplished by chromatography on Silicycle P60 silica gel or Biotage Sfär $60 \mu \mathrm{m}$ silica using a Biotage Isolera One flash chromatography system.

Electrochemical measurements were carried out using a Pine WaveNow PGstat potentiostat connected to a BASi RDE-2 Cell Stand. Cyclic voltammetry (CV) experiments were carried out in a three-electrode cell configuration with a glassy carbon (GC) working electrode (3 $\mathrm{mm}$ diameter) and a platinum wire counter electrode. Working electrode potentials were measured against $\mathrm{Ag} / \mathrm{AgCl}(3 \mathrm{M} \mathrm{KCl})$ aqueous reference electrode or $\mathrm{Ag} / \mathrm{AgNO}_{3}\left(0.1 \mathrm{M} \mathrm{NBu}_{4} \mathrm{PF}_{6}\right.$ in $\left.\mathrm{CH}_{3} \mathrm{CN}\right)$ reference electrode and were referenced to the ferrocene/ferrocenium $\left(\mathrm{Fc} / \mathrm{Fc}^{+}\right)$couple.

Gas uptake experiments were performed in a homemade multi-well reactor system (described below). ${ }^{1}$

\section{Electrochemistry of TEMPO}
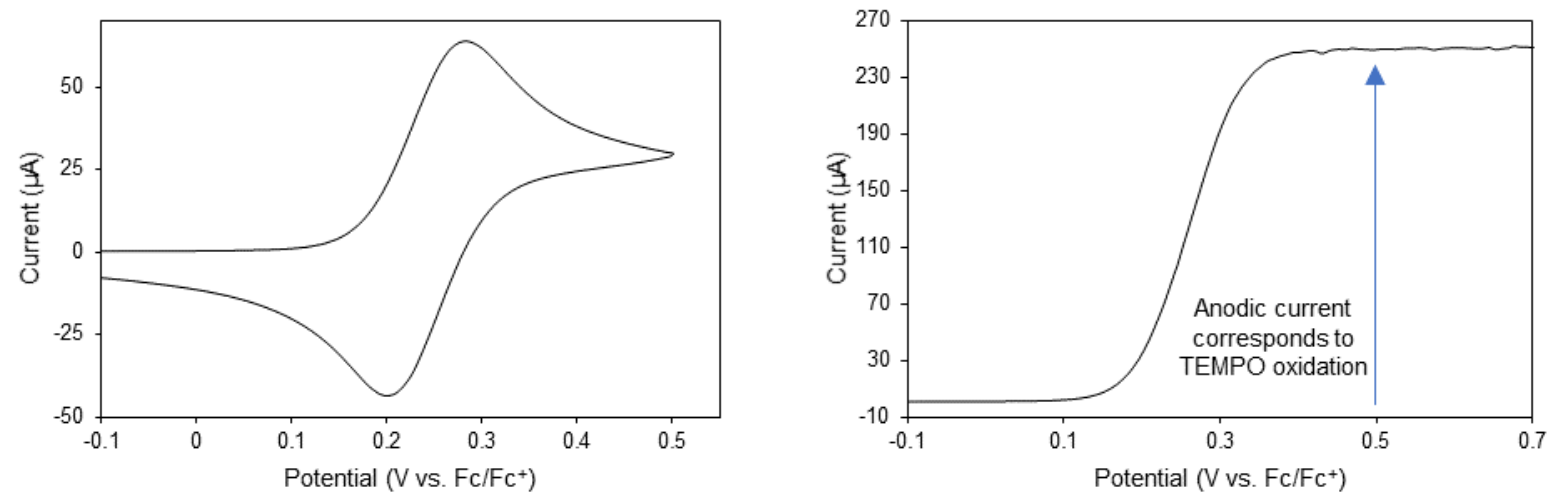

Figure S1. Left: CV of $3 \mathrm{mM}$ TEMPO in $0.1 \mathrm{M} \mathrm{NBu}_{4} \mathrm{PF}_{6} \mathrm{CH}_{3} \mathrm{CN}$. $\mathrm{E}_{1 / 2}=0.24 \mathrm{~V}$ vs. Fc ${ }^{+/ 0}$. Scan rate $=50$ $\mathrm{mV} / \mathrm{s}$. Right: LSV of $3 \mathrm{mM}$ TEMPO in $0.1 \mathrm{M} \mathrm{NBu}_{4} \mathrm{PF}_{6} \mathrm{CH}_{3} \mathrm{CN}$. Scan rate $=50 \mathrm{mV} / \mathrm{s}$, rotation rate $=1000$ RPM.

\section{Cyclic Step Chronoamperometry-Rotating Disk Electrode Experiments}

Aminoxyl speciation in the presence of various reagents was analyzed using cyclic step chronoamperometry (CSCA) at a rotating disk electrode (RDE). For the CSCA experiments, the potential applied at the RDE was alternated at set potentials above and below the nitroxyl/oxoammonium midpoint potential $\left(\mathrm{E}_{1 / 2}=0.24\right.$ $\mathrm{V}$ vs. $\mathrm{Fc}^{+/ 0}$, cf. Fig. S1). One potential is applied for $5 \mathrm{~s}$ to allow the current measured at the working electrode to stabilize and then the potential is stepped to the other set potential and the electrode potential is held at this potential for $5 \mathrm{~s}$. This cycle is repeated until the end of the experiment. During the CSCA experiment, the working glassy carbon electrode is rotated at 1000 RPM to induce convection at the electrode surface. The currents measured at the applied anodic and cathodic potentials during the CSCA experiment are proportional to the concentration of TEMPO and $\mathrm{TEMPO}^{+}$in the electrolyte solution, respectively. ${ }^{2}$ 


\section{3a. $\mathrm{TEMPO/HCl/HNO}$}

To an electrolysis cell mounted in the three-electrode BASi RDE-2 cell stand was added $10 \mathrm{~mL}$ TEMPO solution $(3 \mathrm{mM})$ in supporting electrolyte $\left(0.1 \mathrm{M} \mathrm{NBu}_{4} \mathrm{PF}_{6}, \mathrm{CH}_{3} \mathrm{CN}\right)$. The working electrode was set to rotate at $1000 \mathrm{RPM}$. The CSCA method was initiated with cycling potentials set to $+0.3 /+1.0 \mathrm{~V} \mathrm{vs}$. Ag/AgCl $\left(-0.18 / 0.52 \mathrm{~V}\right.$ vs. $\mathrm{Fc}^{0 /+)}$. Each potential was held for $5 \mathrm{~s}$ before switching to the other. After ca. $1 \mathrm{~min}, 2.5$ $\mu \mathrm{L}$ conc. $\mathrm{HCl}(3 \mathrm{mM})$ was added. At ca. $13 \mathrm{~min}, 2.1 \mu \mathrm{L}$ conc. $\mathrm{HNO}_{3}(3 \mathrm{mM})$ was added. After $22 \mathrm{~min}$, the experiment was stopped.

A time course of [TEMPO] and [TEMPO ${ }^{+}$in the presence of $\mathrm{HCl}$ and $\mathrm{HNO}_{3}$ was determined using the limiting anodic and cathodic currents measured during the CSCA experiment. The median current measured during the $5 \mathrm{~s}$ step period at $1.0 \mathrm{~V}$ vs. $\mathrm{Ag} / \mathrm{AgCl}$ prior to $\mathrm{HCl}$ addition $(239 \mu \mathrm{A})$ was taken as the current proportional to $3 \mathrm{mM}$ TEMPO, $I^{\circ}$ a. At the end of the CSCA experiment, the median cathodic current was $-239 \mu \mathrm{A}$.

The limiting anodic current measured after TEMPO and $\mathrm{HCl}$ (and then $\mathrm{HNO}_{3}$ ) were mixed, $I_{\mathrm{a}}$, is taken as the median current value measured during the $5 \mathrm{~s}$ step period at the anodic potential (i.e., $0.52 \mathrm{~V} \mathrm{vs}$. Fc/Fc' $\mathrm{Fc}^{+}$. This current can be related to [TEMPO] by eq S1. The limiting cathodic current measured after TEMPO and $\mathrm{HCl} / \mathrm{HNO}_{3}$ have been mixed, $I_{\mathrm{c}}$, is taken as the median current value measured during the $5 \mathrm{~s}$ step period at the cathodic potential (i.e., $-0.18 \mathrm{~V}$ vs. $\mathrm{Fc} / \mathrm{Fc}^{+}$). This current can be related to [TEMPO ${ }^{+}$by eq S2

$$
\begin{gathered}
{[\text { TEMPO }]=\frac{I_{a}}{I_{a}^{\circ}} * 3 \mathrm{mM}} \\
{\left[\text { TEMPO }^{+}\right]=-\frac{I_{c}}{I_{a}^{\circ}} * 3 \mathrm{mM}}
\end{gathered}
$$

The resulting CSCA and concentration time course from this experiment is shown in Fig. 1 of the manuscript.

In a separate experiment, LSV/RDE traces of $3 \mathrm{mM}$ TEMPO and the same solution after mixing $20 \mathrm{~min}$ in the presence of $\mathrm{HCl}$ and $\mathrm{HNO}_{3}$ under air were also collected (Fig. S2). These traces show that the cathodic and anodic plateau currents are proportional to the concentrations of TEMPO and TEMPO ${ }^{+}$present in the electrolyte.

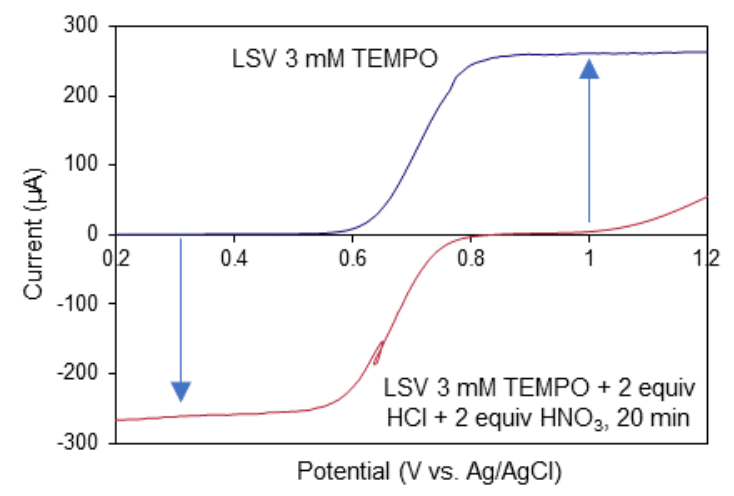

Figure S2. LSV of $3 \mathrm{mM}$ TEMPO (blue) and LSV of a solution of $3 \mathrm{mM}$ TEMPO, $6 \mathrm{mM} \mathrm{HCl}$, and $6 \mathrm{mM}$ $\mathrm{HNO}_{3}$ after $20 \mathrm{~min}$ under air (red). Scan rate $=50 \mathrm{mV} / \mathrm{s}$, rotation rate $=1000 \mathrm{RPM}, 0.1 \mathrm{M} \mathrm{NBu} \mathrm{PF}_{6} \mathrm{CH}_{3} \mathrm{CN}$. 


\section{3b. TEMPO/Fe $\left(\mathrm{NO}_{3}\right)_{3} 9 \mathrm{H}_{2} \mathrm{O}$}

\section{Electrochemistry of $\mathrm{Fe}\left(\mathrm{NO}_{3}\right)_{3} 9 \mathrm{H}_{2} \mathrm{O}$}
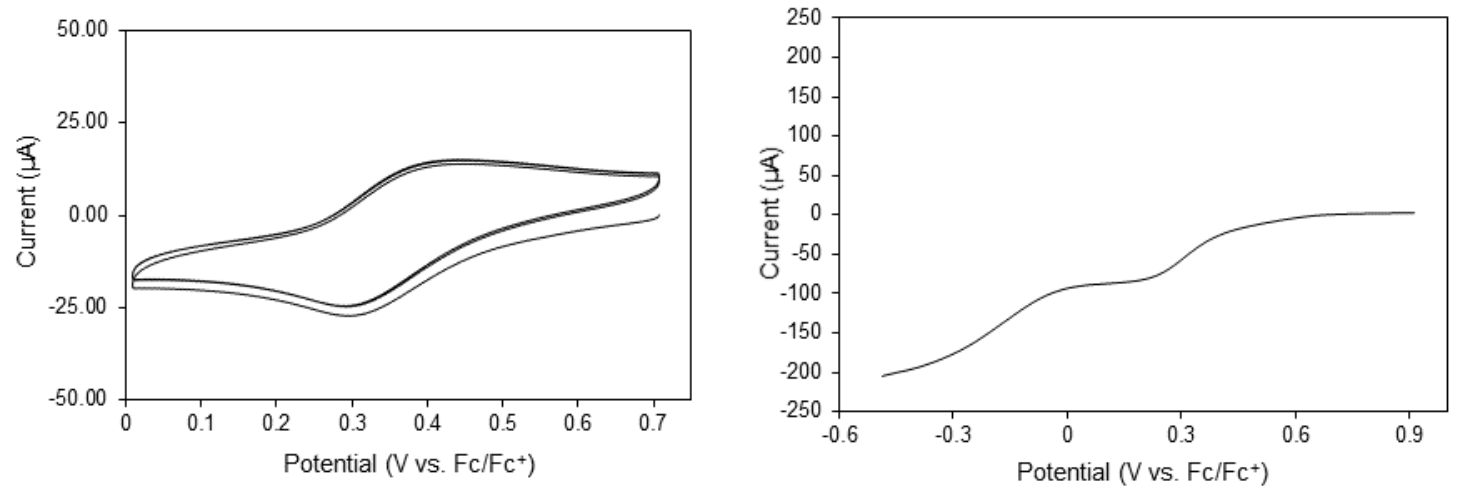

Figure S3. Left: $\mathrm{CV}$ of $3 \mathrm{mM} \mathrm{Fe}\left(\mathrm{NO}_{3}\right)_{3} \cdot 9 \mathrm{H}_{2} \mathrm{O}$ in in $0.1 \mathrm{M} \mathrm{NBu}_{4} \mathrm{PF}_{6} \mathrm{CH}_{3} \mathrm{CN}$. Scan rate $=200 \mathrm{mV} / \mathrm{s}$. Right: $\mathrm{LSV}$ of $6 \mathrm{mM} \mathrm{Fe}\left(\mathrm{NO}_{3}\right)_{3} 9 \mathrm{H}_{2} \mathrm{O}$ in $0.1 \mathrm{M} \mathrm{NBu}_{4} \mathrm{PF}_{6} \mathrm{CH}_{3} \mathrm{CN}$. Scan rate $=50 \mathrm{mV} / \mathrm{s}$, rotation rate $=1000 \mathrm{RPM}$.

\section{CSCA protocol for TEMPO/Fe $\left(\mathrm{NO}_{3}\right)_{3} \cdot 9 \mathrm{H}_{2} \mathrm{O}$}

A typical protocol for obtaining the CSCA data and associated time course of TEMPO speciation in the presence of various $\mathrm{MX}_{\mathrm{n}}$ additives (cf. Figs. 2 and 3 in the manuscript) is exemplified by the analysis of a solution containing a 1:1 ratio of TEMPO:Fe( $\left(\mathrm{NO}_{3}\right)_{3} \cdot 9 \mathrm{H}_{2} \mathrm{O}$. To an electrolysis cell mounted in the BASi RDE-2 cell stand is added $5.5 \mathrm{~mL}$ TEMPO solution $(6 \mathrm{mM})$ in supporting electrolyte $\left(0.1 \mathrm{M} \mathrm{NBu}_{4} \mathrm{PF}_{6}\right.$, $\mathrm{CH}_{3} \mathrm{CN}$ ) under ambient air. The working electrode was set to rotate at $1000 \mathrm{RPM}$ and the CSCA method was then initiated with an anodic potential of $+0.64 /-0.16 \mathrm{~V} \mathrm{vs}$. $\mathrm{Fc} / \mathrm{Fc}^{+}$. The CSCA response of the $6 \mathrm{mM}$ TEMPO solution is monitored for $1 \mathrm{~min}$. This allows the limiting anodic current for a $6 \mathrm{mM}$ solution of TEMPO, $I^{\circ}$ a, to be established. After ca. $1 \mathrm{~min}, 5.5 \mathrm{~mL}$ of a $\mathrm{Fe}\left(\mathrm{NO}_{3}\right)_{3} \cdot 9 \mathrm{H}_{2} \mathrm{O}$ solution $(6 \mathrm{mM})$ in supporting electrolyte $\left(0.1 \mathrm{M} \mathrm{NBu}_{4} \mathrm{PF}_{6}, \mathrm{CH}_{3} \mathrm{CN}\right)$ was quickly added via syringe. Fast addition of this solution facilitates mixing of TEMPO and $\mathrm{Fe}\left(\mathrm{NO}_{3}\right)_{3} \cdot 9 \mathrm{H}_{2} \mathrm{O}$ solutions. The $6 \mathrm{mM} \mathrm{Fe}\left(\mathrm{NO}_{3}\right)_{3} \cdot 9 \mathrm{H}_{2} \mathrm{O}$ solution was prepared by sonicating $\mathrm{Fe}\left(\mathrm{NO}_{3}\right)_{3} \cdot 9 \mathrm{H}_{2} \mathrm{O}$ in supporting electrolyte for ca. $1 \mathrm{~min}$. The CSCA experiment was continued for at least $11 \mathrm{~min}$.

The CSCA experiment was then repeated adding $5.5 \mathrm{~mL}$ of the $6 \mathrm{mM} \mathrm{Fe}\left(\mathrm{NO}_{3}\right)_{3} \cdot 9 \mathrm{H}_{2} \mathrm{O}$ solution in electrolyte first, followed by addition of $5.5 \mathrm{~mL}$ TEMPO $(6 \mathrm{mM}$, in electrolyte $)$ after $1 \mathrm{~min}$ of analysis. By repeating the experiment, the limiting cathodic current, $I^{\circ}$, (from reduction of soluble $\mathrm{Fe}^{\mathrm{III}}$ species) for a $6 \mathrm{mM}$ solution of $\mathrm{Fe}\left(\mathrm{NO}_{3}\right)_{3} \cdot 9 \mathrm{H}_{2} \mathrm{O}$ in supporting electrolyte can be determined. Additionally, $I^{\circ}{ }_{\mathrm{a}}$ and $I^{\circ}{ }_{\mathrm{c}}$ can be determined from the currents measured during a linear sweep voltammetry experiment of the $6 \mathrm{mM}$ TEMPO or $\mathrm{Fe}\left(\mathrm{NO}_{3}\right)_{3} \cdot 9 \mathrm{H}_{2} \mathrm{O}$ solutions. After the CSCA experiment was concluded, a cyclic voltammogram of a solution of $\mathrm{Fc}$ in $0.1 \mathrm{M} \mathrm{NBu}_{4} \mathrm{PF}_{6}, \mathrm{CH}_{3} \mathrm{CN}$ was collected.

A time course of [TEMPO] and [TEMPO ${ }^{+}$in the presence of $\mathrm{Fe}\left(\mathrm{NO}_{3}\right)_{3} \cdot 9 \mathrm{H}_{2} \mathrm{O}$ was determined using the limiting anodic and cathodic currents measured during the CSCA experiment. The limiting anodic current measured after TEMPO and $\mathrm{Fe}\left(\mathrm{NO}_{3}\right)_{3} \cdot 9 \mathrm{H}_{2} \mathrm{O}$ have been mixed, $I_{\mathrm{a}}$, is taken as the median current value measured during the $5 \mathrm{~s}$ step period at the anodic potential. This current can be related to [TEMPO] by eq $\mathrm{S} 3$, which takes into account the dilution of the TEMPO stock solution upon addition of the $\mathrm{Fe}\left(\mathrm{NO}_{3}\right)_{3} \cdot 9 \mathrm{H}_{2} \mathrm{O}$ stock solution. The limiting cathodic current measured after TEMPO and $\mathrm{Fe}\left(\mathrm{NO}_{3}\right)_{3} \cdot 9 \mathrm{H}_{2} \mathrm{O}$ have been mixed, $I_{\mathrm{c}}$, is taken as the median current value measured during the $5 \mathrm{~s}$ step period at the anodic potential. This 
current can be related to [TEMPO ${ }^{+}$by eq $\mathrm{S} 4$, which takes into account the dilution of the TEMPO stock solution upon addition of the $\mathrm{Fe}\left(\mathrm{NO}_{3}\right)_{3} \cdot 9 \mathrm{H}_{2} \mathrm{O}$ stock solution and the background cathodic current due to the presence of $\mathrm{Fe}\left(\mathrm{NO}_{3}\right)_{3} \cdot 9 \mathrm{H}_{2} \mathrm{O}$.

$$
\begin{gathered}
{[T E M P O]=\frac{I_{a}}{\left(0.5 * I^{\circ}{ }_{a}\right)} * 3 \mathrm{mM}} \\
{\left[\mathrm{TEMPO}^{+}\right]=-\frac{I_{c}-\left(0.5 * I^{\circ}{ }_{c}\right)}{\left(0.5 * I^{\circ}{ }_{a}\right)} * 3 \mathrm{mM}}
\end{gathered}
$$

For [TEMPO] and [TEMPO ${ }^{+}$time courses presented in Figures 2 and 3 in the manuscript, the time axes have been adjusted so that $\mathrm{t}=0 \mathrm{~s}$ corresponds to addition of the stock solution to the electrochemical cell.

The above protocol was repeated for solutions of TEMPO in the presence of various additives.
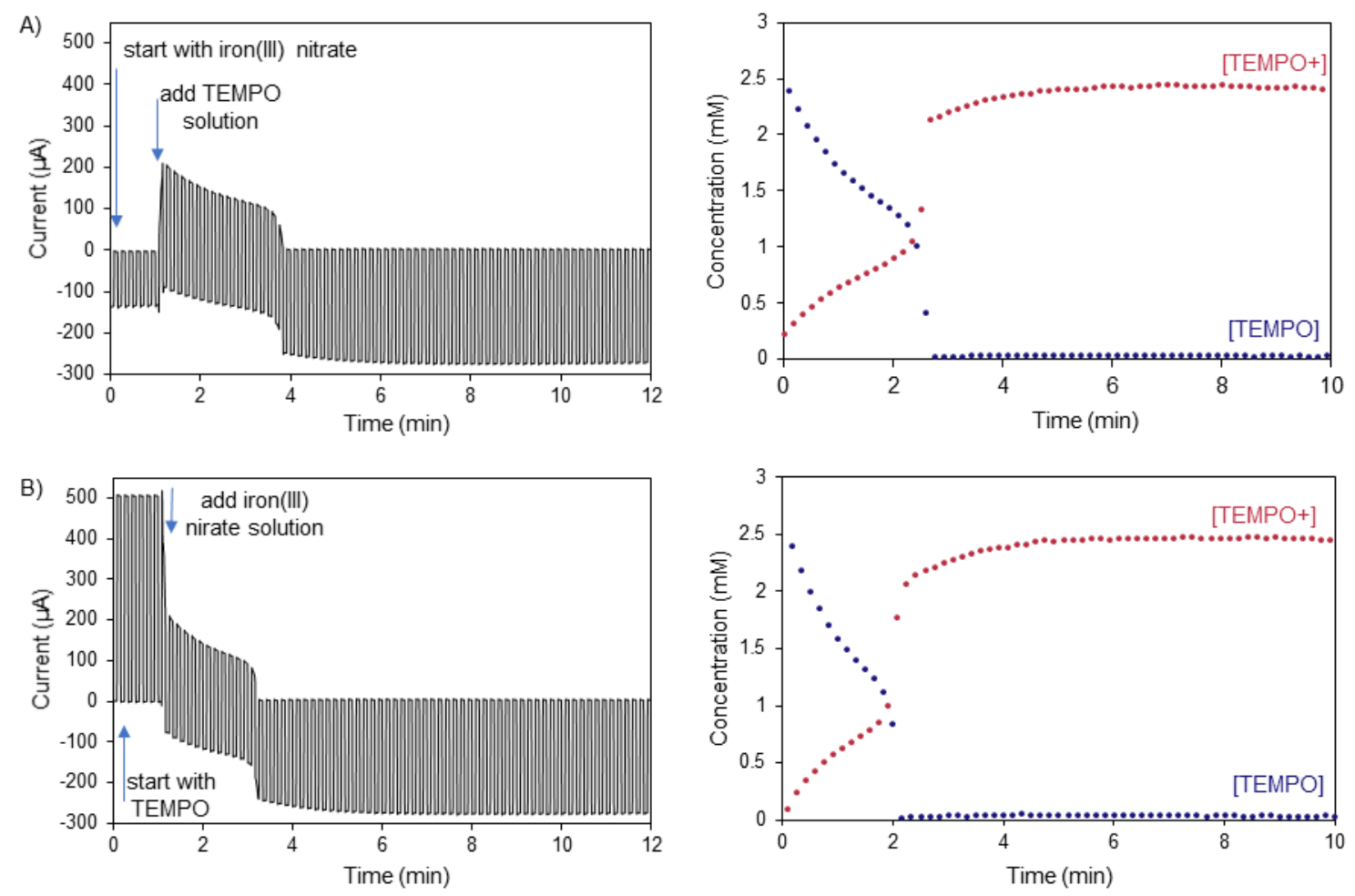

Figure S4. CSCA experiments to analyze a 1:1 solution of TEMPO:Fe( $\left(\mathrm{NO}_{3}\right)_{3} \cdot 9 \mathrm{H}_{2} \mathrm{O}$. A) Left, CSCA data for a solution of $6 \mathrm{mM} \mathrm{Fe}\left(\mathrm{NO}_{3}\right)_{3} \cdot 9 \mathrm{H}_{2} \mathrm{O}$ with addition of a solution of $6 \mathrm{mM}$ TEMPO at $1 \mathrm{~min}$. The limiting cathodic current prior to addition of TEMPO is $-135 \mu \mathrm{A}$. Right, associated [TEMPO] and [TEMPO ${ }^{+}$time course derived from the CSCA data. B) Left, CSCA data for a solution of $6 \mathrm{mM}$ TEMPO followed by addition of a solution of $6 \mathrm{mM} \mathrm{mM} \mathrm{Fe}\left(\mathrm{NO}_{3}\right)_{3} \cdot 9 \mathrm{H}_{2} \mathrm{O}$. Right, associated [TEMPO] and [TEMPO ${ }^{+}$time course derived from the CSCA data. The limiting anodic current prior to addition of $\mathrm{Fe}\left(\mathrm{NO}_{3}\right)_{3} \cdot 9 \mathrm{H}_{2} \mathrm{O}$ is $+505 \mu \mathrm{A}$. The applied anodic and cathodic potentials are $+0.64 /-0.16 \mathrm{~V}$ vs. $\mathrm{Fc} / \mathrm{Fc}^{+}$, respectively. 


\section{3c. TEMPO/Al(OTf $)_{3}$}

To determine if Lewis acid-promoted TEMPO disproportionation could be observed using the CSCA protocol, we monitored the CSCA response of TEMPO in the presence of $\mathrm{Al}(\mathrm{OTf})_{3}$ following the protocol for CSCA analysis of TEMPO/Fe( $\left(\mathrm{NO}_{3}\right)_{3} \cdot 9 \mathrm{H}_{2} \mathrm{O}$ described above. CSCA (Fig. S5) and UV-vis analysis (Fig. S6) of TEMPO in the presence of $\mathrm{Al}(\mathrm{OTf})_{3}$ suggests TEMPO undergoes rapid and complete disproportionation in the presence of $\mathrm{Al}(\mathrm{OTf})_{3}$. Solutions for $\mathrm{UV}$-vis analysis were prepared in an $\mathrm{N}_{2^{-}}$ purged glovebox and measured in a quartz cuvette with a $1 \mathrm{~cm}$ pathlength.
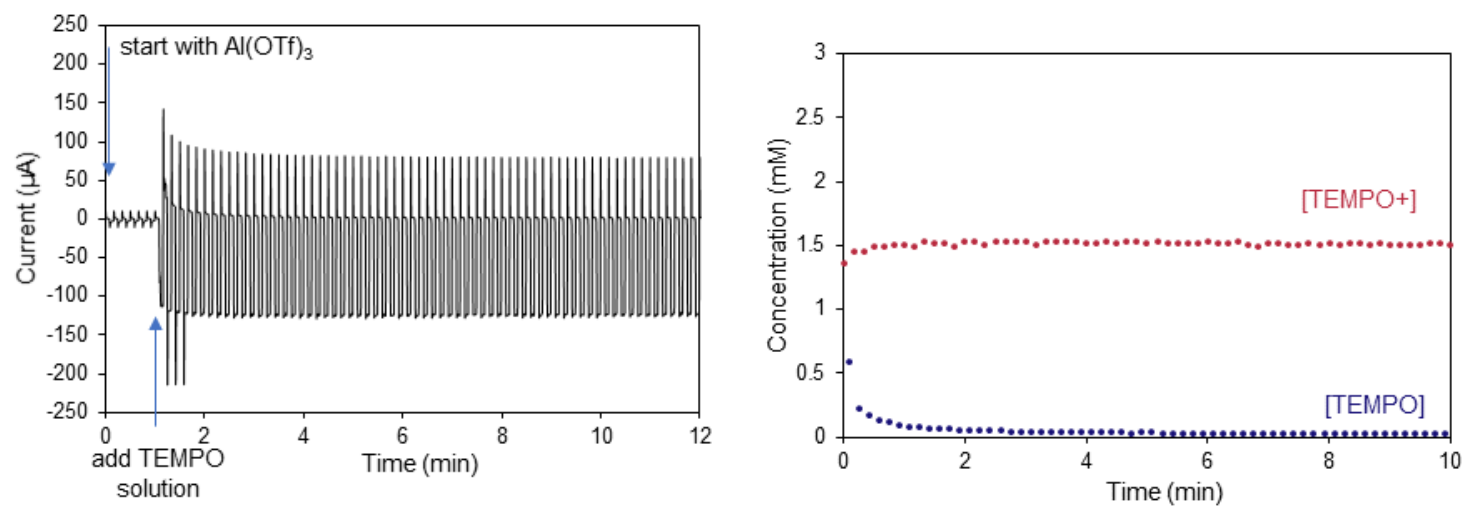

Figure S5. CSCA experiment to analyze a 1:1 solution of TEMPO:Al(OTF $)_{3}$. Left: CSCA data for the time course of 1 equiv $\mathrm{Al}(\mathrm{OTf})_{3}$ and 1 equiv TEMPO. The CSCA begins with a solution of $6 \mathrm{mM} \mathrm{Al}(\mathrm{OTf})_{3}$ followed by addition of a solution of $6 \mathrm{mM}$ TEMPO. Right, associated [TEMPO], [TEMPO ${ }^{+}$time course derived from the CSCA data. The applied anodic and cathodic potentials are $+0.66 /-0.15 \mathrm{~V} \mathrm{vs}$. $\mathrm{Fc} / \mathrm{Fc}^{+}$, respectively. The anodic potential of the $6 \mathrm{mM}$ TEMPO stock solution for this experiment was measured at $+491 \mu \mathrm{A}$.

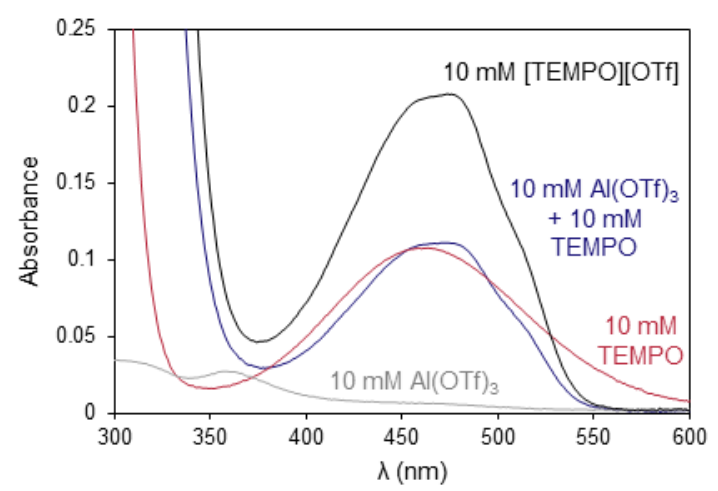

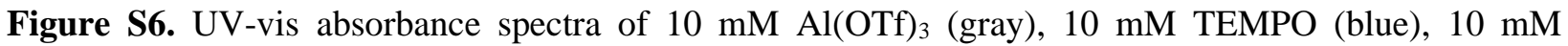
TEMPO[OTf], and the spectrum recorded upon mixing $10 \mathrm{mM} \mathrm{Al}(\mathrm{OTf})_{3}$ and $10 \mathrm{mM}$ TEMPO (red) in $\mathrm{CH}_{3} \mathrm{CN}$. 


\section{3d. TEMPO/Zn( $\left(\mathrm{NO}_{3}\right)_{3} \cdot 6 \mathrm{H}_{2} \mathrm{O}$ and TEMPO/Al(OTf $)_{3}, \mathrm{NBu}_{4} \mathrm{NO}_{3}$}

The CSCA protocol was used to examine the reaction of TEMPO with other metal nitrate salts. Zinc nitrate is a redox inactive metal nitrate salt. Under the CSCA analysis conditions, no significant consumption of TEMPO or formation of TEMPO ${ }^{+}$was observed in the presence of $\mathrm{Zn}\left(\mathrm{NO}_{3}\right)_{2}$ (Fig. S7).
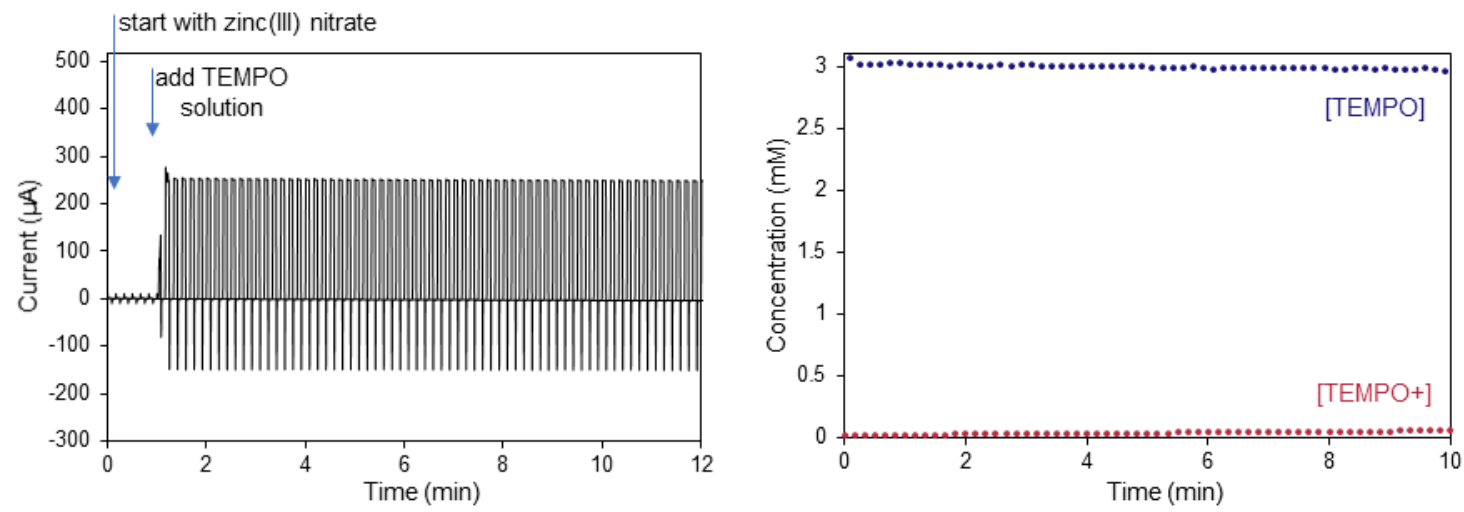

Figure S7. CSCA experiment to analyze a 1:1 solution of TEMPO: $\mathrm{Zn}\left(\mathrm{NO}_{3}\right)_{2} \cdot 6 \mathrm{H}_{2} \mathrm{O}$. Left: CSCA data for the time course of 1 equiv $\mathrm{Zn}\left(\mathrm{NO}_{3}\right)_{2} \cdot 6 \mathrm{H}_{2} \mathrm{O}$ and 1 equiv TEMPO. The CSCA begins with $6 \mathrm{mM}$ $\mathrm{Zn}\left(\mathrm{NO}_{3}\right)_{2} \cdot 6 \mathrm{H}_{2} \mathrm{O}$ followed by addition of a solution of $6 \mathrm{mM}$ TEMPO. Right: associated [TEMPO], $\left[\mathrm{TEMPO}^{+}\right]$time course derived from the CSCA data. The applied anodic and cathodic potentials are 0.66/$0.15 \mathrm{~V} \mathrm{vs}$. Fc/Fc $\mathrm{Fc}^{+}$, respectively. The anodic potential of the $6 \mathrm{mM}$ TEMPO stock solution for this experiment was measured at $+500 \mu \mathrm{A}$.

Aluminum(III) nitrate was not soluble in the $\mathrm{CH}_{3} \mathrm{CN}$ electrolyte. Instead, the CSCA protocol was used to analyze a solution of TEMPO in the presence of 1 equivalent of $\mathrm{Al}(\mathrm{OTf})_{3}$ with 3 equivalents of $\mathrm{NBu}_{4} \mathrm{NO}_{3}$. CSCA analysis (Fig. S8) of this solution suggests TEMPO undergoes slow and incomplete disproportionation in the presence of $\mathrm{Al}(\mathrm{OTf})_{3}$ and $\mathrm{NBu}_{4} \mathrm{NO}_{3}$ under the time scale of the experiment.
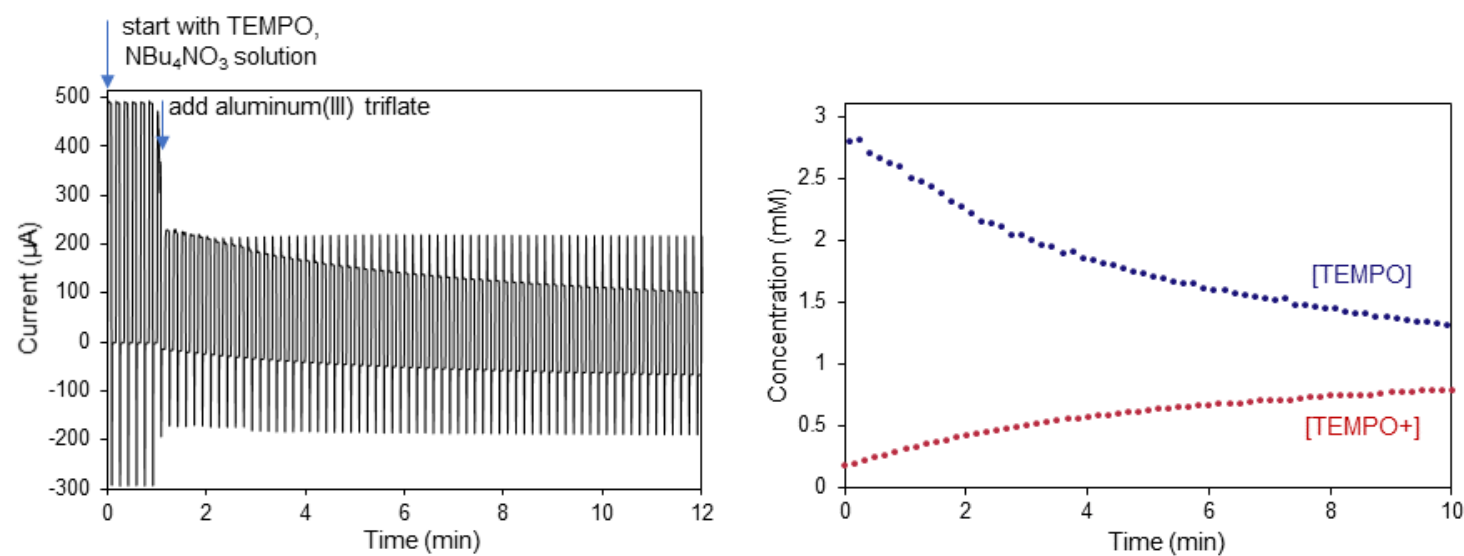

Figure S8. CSCA experiment to analyze a 1:1:3 solution of TEMPO:Al(OTf $)_{3}: \mathrm{NBu}_{4} \mathrm{NO}_{3}$. Left: CSCA data for the time course of 1 equiv $\mathrm{Al}(\mathrm{OTf})_{3}, 3$ equiv. $\mathrm{NBu}_{4} \mathrm{NO}_{3}$ and 1 equiv TEMPO. The CSCA begins with a solution of $6 \mathrm{mM}$ TEMPO and $18 \mathrm{mM} \mathrm{NBu}_{4} \mathrm{NO}_{3}$ followed by addition of a solution of $6 \mathrm{mM} \mathrm{Al}(\mathrm{OTf})_{3}$. Right: associated [TEMPO], [TEMPO ${ }^{+}$] time course derived from the CSCA data. The applied anodic and cathodic potentials are $+0.66 /-0.15 \mathrm{~V}$ vs. $\mathrm{Fc} / \mathrm{Fc}^{+}$, respectively. The anodic potential of the $6 \mathrm{mM}$ TEMPO stock solution for this experiment was measured at $+495 \mu \mathrm{A}$. 


\section{3e. TEMPO/Fe(OTf $)_{3}$}

The CSCA protocol was used to examine the reaction of TEMPO with other iron(III) species. The CSCA protocol was attempted with iron(III) triflate. At the potentials examined, iron(III) triflate is electrochemically active. Unlike iron(III) nitrate, however, the limiting currents measured for a solution of $6 \mathrm{mM}$ iron(III) triflate under the same CSCA analysis conditions change over time (cf. Fig. S9, 0-3 min). The background current arising from iron(III) triflate at both the anodic and cathodic steps was taken as the median currents measured in the two CSCA steps immediately prior to addition of the TEMPO solution.
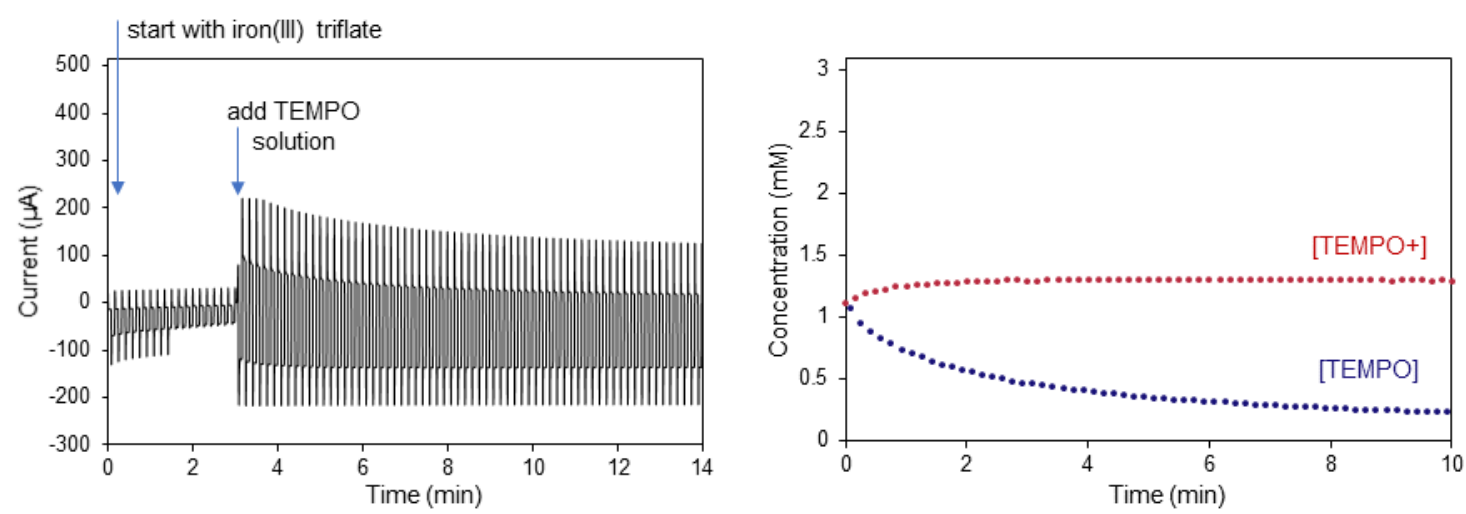

Figure S9. CSCA experiment to analyze a 1:1 solution of TEMPO:Fe(OTf) $)_{3}$. Left: CSCA data for the time course of 1 equiv $\mathrm{Fe}(\mathrm{OTf})_{3}$ and 1 equiv TEMPO. The CSCA begins with $6 \mathrm{mM} \mathrm{Fe}(\mathrm{OTf})_{3}$ followed by addition of a solution of $6 \mathrm{mM}$ TEMPO at ca. $3 \mathrm{~min}$. Right: associated [TEMPO], [TEMPO ${ }^{+}$time course derived from the CSCA data. The applied anodic and cathodic potentials are $+0.66 /-0.15 \mathrm{~V} v \mathrm{vs}$. Fc/Fc $\mathrm{Fc}^{+}$, respectively. The anodic potential of the $6 \mathrm{mM}$ TEMPO stock solution for this experiment was measured at $+537 \mu \mathrm{A}$. Prior to addition of the $6 \mathrm{mM}$ TEMPO solution, the measured median current for the $6 \mathrm{mM}$ $\mathrm{Fe}(\mathrm{OTf})_{3}$ solution during the anodic step and cathodic step was $-6 \mu \mathrm{A}$ and $-42 \mu \mathrm{A}$, respectively.

\section{Gas Uptake Protocol}

The gas uptake apparatus has been described previously. ${ }^{1}$ Reactions were carried out in heavy-walled glass microwave tubes $(10 \mathrm{~mL}$ volume) with $15 \mathrm{~mm}$ oval stir bars. The tubes were capped with a gas-tight manifold containing a gas/vacuum inlet, pressure transducer (Omega Engineering), septum cap, and pressure release valve. The gas vacuum inlet was attached by a T-junction to a diaphragm vacuum pump and a tank of $\mathrm{O}_{2}$ gas. The individual reactors were placed in an aluminum heating block placed on top of an IKA multi stir plate. The reactor pressure was monitored using a Python based software with RasberriPi centric hardware.

\section{Protocol for gas uptake kinetics of the TEMPO/iron(III) nitrate system}

The gas uptake reactor was preheated to $35{ }^{\circ} \mathrm{C}$ (minimum stable temperature accessible due to heating effects of the stir plate). To a heavy-walled glass test tube was added a stir bar, $0.05 \mathrm{mmol} \mathrm{Fe}\left(\mathrm{NO}_{3}\right)_{3} 9 \mathrm{H}_{2} \mathrm{O}$, $0.05 \mathrm{mmol} \mathrm{KCl}$, and $0.8 \mathrm{~mL} \mathrm{1,2-dichloroethane.} \mathrm{An} \mathrm{evacuation/refill} \mathrm{cycle} \mathrm{was} \mathrm{performed} \mathrm{to} \mathrm{place} \mathrm{the}$ reactor under an $\mathrm{O}_{2}$ atmosphere of 17 psi. The reactor was then sealed, and the monitored pressure was allowed to stabilize (ca. $25 \mathrm{~min}$ ). After the pressure stabilized, $0.1 \mathrm{~mL}$ of a stock solution of TEMPO in 1,2-dichloroethane $(50 \mathrm{mM})$ was added. After $5 \mathrm{~min}, 0.1 \mathrm{~mL}$ of a stock solution containing substrate (cyclohexanol or cyclohexanemethanol, $1 \mathrm{M}$ ) in 1,2-dichloroethane was added. The change in pressure within the reactor was monitored for $20 \mathrm{~h}$. The pressure in an additional reactor containing $1 \mathrm{~mL} \mathrm{1,2-}$ dichloroethane was also monitored during the experiment. After the experiment was concluded, the reactors were cooled to ambient temperature. Bromobenzene $(8 \mu \mathrm{L})$ was added to each reaction solution, which were then diluted with $\mathrm{CH}_{3} \mathrm{CN}$, filtered through a short silica plug, and analyzed by gas chromatography. 
Yields of ketone/aldehyde product and recovered starting material were determined compared to the bromobenzene standard.

\section{Protocol for gas uptake kinetics of the TEMPO/Cu(I) system}

The gas uptake reactor was preheated to $35{ }^{\circ} \mathrm{C}$ (minimum stable temperature accessible due to heating effects of the attached stir plate). To a heavy-walled glass microwave tube was added a stir bar, $0.1 \mathrm{mmol}$ cyclohexanol (or cyclohexanemethanol), and $0.9 \mathrm{~mL} \mathrm{CH}_{3} \mathrm{CN}$. An evacuation/refill cycle was performed to place the reactor under an $\mathrm{O}_{2}$ atmosphere of $17 \mathrm{psi}$. The reactor was then sealed, and the monitored pressure was allowed to stabilize (ca. $25 \mathrm{~min}$ ). After the pressure stabilized, $0.1 \mathrm{~mL}$ of a freshly prepared stock solution containing $50 \mathrm{mM}$ TEMPO, $50 \mathrm{mM}\left[\mathrm{Cu}\left(\mathrm{CH}_{3} \mathrm{CN}\right)_{4}\right] \mathrm{BF}_{4}, 50 \mathrm{mM}$ 2,2'-bpy, $100 \mathrm{mM}$ 1methylimidazole in $\mathrm{CH}_{3} \mathrm{CN}$ was added. The change in pressure within the reactor was monitored for $20 \mathrm{~h}$. The pressure in an additional reactor containing $1 \mathrm{~mL} \mathrm{CH}_{3} \mathrm{CN}$ was also monitored during the experiment. After the experiment was concluded, the reactors were cooled to ambient temperature. Bromobenzene ( 8 $\mu \mathrm{L}$ ) was added to each reaction solution, which were then diluted with $\mathrm{CH}_{3} \mathrm{CN}$, filtered through a short silica plug, and analyzed by gas chromatography. Yields of ketone/aldehyde product and recovered starting material were determined compared to the bromobenzene standard.

The pressure traces shown in Fig. 4 of the manuscript were worked up as follows:

The pressure measured in the reactor containing only solvent was subtracted from the pressure traces of the reactors containing corresponding reactions. The measured absolute pressure values were then converted to the change of $\mathrm{O}_{2}$ pressure in $\mu \mathrm{mol} \mathrm{O}_{2}$ (as determined by the ideal gas law).

\section{Gas Chromatography (GC) Time Course of TEMPO/iron(III) nitrate system}

TEMPO (0.01 mmol), $\mathrm{Fe}\left(\mathrm{NO}_{3}\right)_{3} 9 \mathrm{H}_{2} \mathrm{O}(0.01 \mathrm{mmol})$, and $\mathrm{KCl}(0.01 \mathrm{mmol})$ were added to a 1.5 -dram vial with a stir bar. To the vial was added $\mathrm{C}_{2} \mathrm{H}_{4} \mathrm{Cl}_{2}(0.5 \mathrm{~mL})$. The vial was capped with a septum, which was then pierced with a needle attached to a balloon of $\mathrm{O}_{2}$. The solution was stirred under $\mathrm{O}_{2}$ for 5 min, after which $0.5 \mathrm{~mL}$ of a stock solution containing $0.2 \mathrm{M}$ cyclohexanol or cyclohexanemethanol $(0.1 \mathrm{mmol})$ and $0.1 \mathrm{M} \mathrm{PhBr}(0.05 \mathrm{mmol})$ was added. At given times, $40 \mu \mathrm{L}$ aliquots of the reaction solution were withdrawn, filtered through a short plug of $\mathrm{SiO}_{2}$ with added $\mathrm{CH}_{3} \mathrm{CN}$, and analyzed by GC. Conditions: $70{ }^{\circ} \mathrm{C}$, hold 1 min, then $70{ }^{\circ} \mathrm{C}$ to $200{ }^{\circ} \mathrm{C}, 20 \mathrm{deg} / \mathrm{min}$. Retention times: $\mathrm{PhBr}, 4.3 \mathrm{~min}$; cyclohexanol, $4.6 \mathrm{~min}$; cyclohexanone, $3.9 \mathrm{~min}$; cyclohexanemethanol, $5.6 \mathrm{~min}$; cyclohexane carboxaldehyde, $3.75 \mathrm{~min}$.

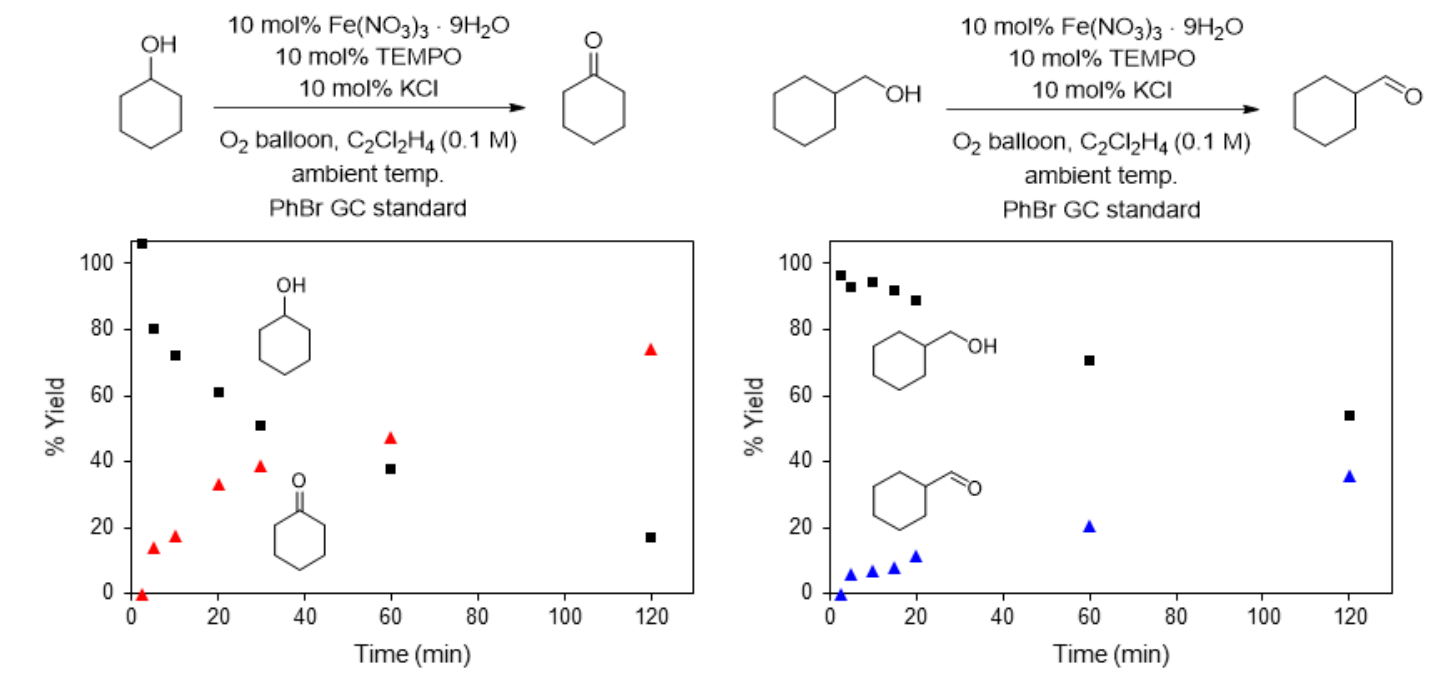

Figure S10. Time courses for the iron(III) nitrate/TEMPO-catalyzed aerobic oxidation of cyclohexanol and cyclohexanemethanol. Monitored by GC with $\mathrm{PhBr}$ internal standard. 


\section{Synthesis of [TEMPO]CF $\mathrm{SOO}_{3}$}<smiles>CC1(C)CCCC(C)(C)N1C(=O)O[Si]</smiles>

Synthesis of 2,2,6,6-tetramethylpiperidin-1-oxoammonium trifluoromethane sulfonate (TEMPO ${ }^{+}$ OTf $)^{3}$ To a stirred solution of TEMPO $(917 \mathrm{mg}, 5.9 \mathrm{mmol})$ in diethyl ether $(3 \mathrm{~mL})$ cooled to $0{ }^{\circ} \mathrm{C}$ was added trifluoromethane sulfonic acid $(0.5 \mathrm{~mL}, 5.7 \mathrm{mmol})$ dropwise. After stirring for $15 \mathrm{~min}$, commercial bleach $(4 \mathrm{~mL})$ was added dropwise. The reaction was allowed to stir for an additional $30 \mathrm{~min}$ at $0{ }^{\circ} \mathrm{C}$. The orange-yellow precipitate was then collected via vacuum filtration and washed with $5 \% \mathrm{NaHCO}_{3}(2 \mathrm{~mL})$, $\mathrm{H}_{2} \mathrm{O}(2 \mathrm{~mL})$, and diethyl ether $(10 \mathrm{~mL})$. All washing solutions were chilled in a $0{ }^{\circ} \mathrm{C}$ ice bath before washing the orange-yellow precipitate. After washing, the orange-yellow solid $(260 \mathrm{mg})$ was dried under vacuum. Anal. Calcd. For $\mathrm{C}_{10} \mathrm{H}_{18} \mathrm{~F}_{3} \mathrm{NO}_{4} \mathrm{~S}=0.2 \mathrm{H}_{2} \mathrm{O}$ C, 38.9; H, 6.00; N, 4.53. Found: C, 38.80; H, 5.86; N, 4.51.

\section{Synthesis of Alcohol Substrates}<smiles>CC(O)c1ccc(CO)cc1</smiles>

Synthesis of 4-(1'-hydroxyethyl)benzyl alcohol (1). ${ }^{4}$ To an oven dried $250 \mathrm{~mL}$ round bottom flask, $1.0 \mathrm{~g}$ $(26 \mathrm{mmol})$ of $\mathrm{LiAlH}_{4}$ was added under $\mathrm{N}_{2}$. Dry THF $(50 \mathrm{~mL})$ was added and the flask was cooled to $0{ }^{\circ} \mathrm{C}$. To an oven dried $100 \mathrm{~mL}$ round bottom flask was added $0.89 \mathrm{~g}(5 \mathrm{mmol})$ methyl-4-acetylbenzoate. The flask was placed under an $\mathrm{N}_{2}$ atmosphere and $30 \mathrm{~mL}$ dry THF was added. The flask containing substrate was cooled to $0{ }^{\circ} \mathrm{C}$. The solution of substrate was then transferred dropwise to the flask containing the $\mathrm{LiAlH}_{4}$ suspension via cannula. The reaction was then allowed to warm to room temperature overnight. The reaction was quenched by sequential slow addition of $50 \mathrm{~mL}$ EtOAc, $1 \mathrm{~mL} \mathrm{H}_{2} \mathrm{O}, 1 \mathrm{~mL} 0.1 \mathrm{M} \mathrm{NaOH}_{(\mathrm{aq})}$ at $0{ }^{\circ} \mathrm{C}$ and then $3 \mathrm{~mL} \mathrm{H}_{2} \mathrm{O}$ at ambient temperature. The resulting white solids were removed via filtration and the filtrate was transferred to a separatory funnel containing $50 \mathrm{~mL} \mathrm{H}_{2} \mathrm{O}$. The aqueous layer was extracted with $3 \times 50 \mathrm{~mL}$ EtOAc. The organic layers were combined, dried over $\mathrm{MgSO}_{4}$, filtered, and dried in vacuo. The diol product was further purified by flash column chromatography (2:1 EtOAc:Pentane) to give a white solid. Yield $0.486 \mathrm{~g}(64 \%$ yield $)$.

${ }^{1} \mathrm{H}$ NMR (500 MHz, Chloroform- $d$ ) $\delta 7.40-7.32(\mathrm{~m}, 5 \mathrm{H}), 4.90(\mathrm{q}, J=6.4 \mathrm{~Hz}, 1 \mathrm{H}), 4.68(\mathrm{~s}, 2 \mathrm{H}), 1.89$ (bs, $1 \mathrm{H}), 1.77(\mathrm{bs}, 1 \mathrm{H}), 1.49(\mathrm{~d}, J=6.3 \mathrm{~Hz}, 3 \mathrm{H}) .{ }^{13} \mathrm{C} \mathrm{NMR}\left(126 \mathrm{MHz}, \mathrm{CDCl}_{3}\right) \delta 145.29,140.11,127.20,125.62$, $70.18,65.10,25.21$. Spectral properties are consistent with literature values. ${ }^{4}$<smiles>OCCCCCC(O)c1ccccc1</smiles>

Synthesis of 1-phenylhexane-1,6 diol (5). ${ }^{4}$ To an oven dried $250 \mathrm{~mL}$ round bottom flask, $1.0 \mathrm{~g}(26 \mathrm{mmol})$ of $\mathrm{LiAlH}_{4}$ were added under $\mathrm{N}_{2}$. Dry THF $(50 \mathrm{~mL})$ was added and the flask was cooled to $0{ }^{\circ} \mathrm{C}$. To an oven dried $100 \mathrm{~mL}$ round bottom flask was added $1.0 \mathrm{~g}(4.8 \mathrm{mmol}) 5$-benzoylpentanoic acid. The flask was placed under an $\mathrm{N}_{2}$ atmosphere and $30 \mathrm{~mL}$ dry THF was added. The flask containing substrate was cooled to $0{ }^{\circ} \mathrm{C}$. The solution of substrate was then transferred dropwise to the flask containing the $\mathrm{LiAlH}_{4}$ suspension via cannula. The reaction was then allowed to warm to room temperature overnight. The reaction was quenched by sequential slow addition of $50 \mathrm{~mL}$ EtOAc, $1 \mathrm{~mL} \mathrm{H}_{2} \mathrm{O}, 1 \mathrm{~mL} 0.1 \mathrm{M} \mathrm{NaOH}_{(\mathrm{aq})}$ at 
$0{ }^{\circ} \mathrm{C}$ and then $3 \mathrm{~mL} \mathrm{H}_{2} \mathrm{O}$ at ambient temperature. The resulting white solids were removed via filtration and the filtrate was transferred to a separatory funnel containing $50 \mathrm{~mL} \mathrm{H}_{2} \mathrm{O}$. The aqueous layer was extracted with $3 \times 30 \mathrm{~mL}$ EtOAc. The organic layers were combined, dried over $\mathrm{MgSO}_{4}$, filtered, and dried in vacuo. The diol product was further purified by flash column chromatography $\left(1-5 \% \mathrm{MeOH}\right.$ in $\left.\mathrm{CH}_{2} \mathrm{Cl}_{2}\right)$ to give a white solid. Yield $0.842 \mathrm{~g}$ (90\% yield).

${ }^{1} \mathrm{H}$ NMR (500 MHz, Chloroform- $d$ ) $\delta 7.34(\mathrm{~d}, J=5.5 \mathrm{~Hz}, 4 \mathrm{H}), 7.30-7.25(\mathrm{~m}, 1 \mathrm{H}), 4.66(\mathrm{t}, J=6.7 \mathrm{~Hz}$, $1 \mathrm{H}), 3.61(\mathrm{t}, J=6.5 \mathrm{~Hz}, 2 \mathrm{H}), 2.03(\mathrm{bs}, 1 \mathrm{H}), 1.81(\mathrm{~m}, 1 \mathrm{H}), 1.71(\mathrm{~m}, 1 \mathrm{H}), 1.55(\mathrm{p}, J=6.8 \mathrm{~Hz}, 2 \mathrm{H}), 1.49-$ $1.26(\mathrm{~m}, 5 \mathrm{H}) .{ }^{13} \mathrm{C} \mathrm{NMR}\left(126 \mathrm{MHz}, \mathrm{CDCl}_{3}\right) \delta 144.98,128.58,127.65,126.00,74.67,62.97,39.12,32.73$, $25.75,25.70$. Spectral properties are consistent with literature values. ${ }^{4}$<smiles>OCc1ccnc2ccccc12</smiles>

Synthesis of 4-quinoylmethanol (9). ${ }^{5}$ To a $100 \mathrm{~mL}$ round bottom flask was added $1.572 \mathrm{~g} \mathrm{(10} \mathrm{mmol)} \mathrm{4-}$ quinoline carboxaldehyde and $40 \mathrm{~mL} \mathrm{MeOH}$. To a stirred solution of substrate was added $0.431 \mathrm{~g} \mathrm{(11.4}$ mmol) $\mathrm{NaBH}_{4}$ portion-wise over $20 \mathrm{~min}$. The solution was allowed to stir overnight, after which the reaction solution was poured into a separatory funnel containing $100 \mathrm{~mL}$ saturated $\mathrm{NH}_{4} \mathrm{Cl}_{(\text {aq) }}$ solution. The aqueous layer was extracted with $3 \times 50 \mathrm{~mL}$ EtOAc. The organic layers were combined, dried over $\mathrm{MgSO}_{4}$, filtered, and dried in vacuo. The product was further purified by flash column chromatography $(2-10 \% \mathrm{MeOH}$ in $\mathrm{CH}_{2} \mathrm{Cl}_{2}$ ) to give a white solid. Yield $1.241 \mathrm{~g} 78 \%$ yield).

${ }^{1} \mathrm{H}$ NMR (500 MHz, DMSO) $\delta 8.87(\mathrm{~d}, J=4.3 \mathrm{~Hz}, 1 \mathrm{H}), 8.04(\mathrm{t}, J=8.2 \mathrm{~Hz}, 2 \mathrm{H}), 7.79-7.72(\mathrm{~m}, 1 \mathrm{H}), 7.63$ $-7.59(\mathrm{~m}, 1 \mathrm{H}), 7.58(\mathrm{~d}, J=4.3 \mathrm{~Hz}, 1 \mathrm{H}), 5.57(\mathrm{t}, J=5.5 \mathrm{~Hz}, 1 \mathrm{H}), 5.04(\mathrm{~d}, J=5.5 \mathrm{~Hz}, 2 \mathrm{H}) .{ }^{13} \mathrm{C}$ NMR $(126$ MHz, DMSO) $\delta 150.40,147.63,147.30,129.47,129.03,126.32,125.43,123.49,118.01,59.63$. HRMS (ESI) exact mass calculated for $[\mathrm{M}+\mathrm{H}]+\left(\mathrm{C}_{10} \mathrm{H}_{10} \mathrm{NO}\right)$ requires $\mathrm{m} / \mathrm{z} 160.0757$, found $\mathrm{m} / \mathrm{z} 160.0756$, difference $0.6 \mathrm{ppm}$.

\section{NMR Yields (0.1 mmol Scale) for Oxidation of 1 and 5}

The aerobic oxidation of $\mathbf{1}$ and $\mathbf{5}$ by the various TEMPO/co-catalyst systems was first examined at small scale $(0.1 \mathrm{mmol})$ to determine trends in the chemoselectivity. The reaction times and NMR yields for the oxidation of $\mathbf{1}$ and $\mathbf{5}$ are reported in Table S1 and Table S2, respectively.

Oxidation of 4-(1'-hydroxyethyl)benzyl alcohol (1, 0.1 mmol) by TEMPO/Cu:

TEMPO (0.005 mmol), [Cu( $\left.\left.\mathrm{CH}_{3} \mathrm{CN}\right)_{4}\right] \mathrm{BF}_{4}(0.005 \mathrm{mmol}), 2,2^{\prime}$-dipyridyl (bpy) $(0.005 \mathrm{mmol})$, and $N$-methyl imidazole $(0.01 \mathrm{mmol})$ were added to a 1.5 -dram vial with a stir bar. To the vial was added $\mathrm{CH}_{3} \mathrm{CN}(1 \mathrm{~mL})$ and $1(0.1 \mathrm{mmol})$. The vial was capped with a septum which was pierced with an 18 -gauge needle. The reaction was stirred rapidly open to air and was followed by TLC. The reaction was diluted with $\mathrm{CH}_{3} \mathrm{CN}$ and passed through a silica plug. To the filtrate was added 1,3,5-trimethoxybenzene. Solvent was removed in vacuo and the residue was analyzed by ${ }^{1} \mathrm{H}$ NMR in $\mathrm{CDCl}_{3}$.

Oxidation of 4-(1'-hydroxyethyl)benzyl alcohol $(1,0.1 \mathrm{mmol})$ by TEMPO/iron(III) nitrate in $\mathrm{CH}_{3} \mathrm{CN}$ : TEMPO $(0.005 \mathrm{mmol})$ and $\mathrm{Fe}\left(\mathrm{NO}_{3}\right)_{3} 9 \mathrm{H}_{2} \mathrm{O}(0.005 \mathrm{mmol})$ were added to a 1.5 -dram vial with a stir bar. To the vial was added $\mathrm{CH}_{3} \mathrm{CN}(1 \mathrm{~mL})$. The solution was stirred rapidly open to air for $5 \mathrm{~min}$, after which $1(0.1$ mmol) was added. The vial was capped with a septum which was pierced with an 18-gauge needle. The reaction was stirred rapidly open to air and was followed by TLC. The reaction was diluted with $\mathrm{CH}_{3} \mathrm{CN}$ 
and passed through a silica plug. To the filtrate was added 1,3,5-trimethoxybenzene. Solvent was removed in vacuo and the residue was analyzed by ${ }^{1} \mathrm{H}$ NMR in $\mathrm{CDCl}_{3}$.

Oxidation of 4-(1'-hydroxyethyl)benzyl alcohol (1, 0.1 mmol) by TEMPO/iron(III) nitrate in $\mathrm{C}_{2} \mathrm{H}_{4} \mathrm{Cl}_{2}$ : TEMPO (0.005 mmol), $\mathrm{Fe}\left(\mathrm{NO}_{3}\right)_{3} 9_{2} \mathrm{H}_{2} \mathrm{O}(0.005 \mathrm{mmol})$, and $\mathrm{KCl}(0.005 \mathrm{mmol})$ were added to a 1.5 -dram vial with a stir bar. To the vial was added $\mathrm{C}_{2} \mathrm{H}_{4} \mathrm{Cl}_{2}(1 \mathrm{~mL})$. The solution was stirred rapidly open to air for $5 \mathrm{~min}$, after which $1(0.1 \mathrm{mmol})$ was added. The vial was capped with a septum which was pierced with an 18-gauge needle. The reaction was stirred rapidly open to air and was followed by TLC. The reaction was diluted with $\mathrm{CH}_{3} \mathrm{CN}$ and passed through a silica plug. To the filtrate was added 1,3,5-trimethoxybenzene. Solvent was removed in vacuo and the residue was analyzed by ${ }^{1} \mathrm{H} \mathrm{NMR}$ in $\mathrm{CDCl}_{3}$.

Oxidation of 4-(1'-hydroxyethyl)benzyl alcohol $(1,0.1 \mathrm{mmol})$ by TEMPO/NO

TEMPO $(0.005 \mathrm{mmol})$ and $\mathrm{NaNO}_{2}(0.01 \mathrm{mmol})$ were added to a 1.5 -dram vial with a stir bar. To the vial was added $\mathrm{CH}_{3} \mathrm{CN}(1 \mathrm{~mL}), 1(0.1 \mathrm{mmol})$, and then $\mathrm{HNO}_{3}(0.02 \mathrm{mmol})$. The vial was capped with a septum which was pierced with an 18-gauge needle. The reaction was stirred rapidly open to air and was followed by TLC. The reaction was diluted with $\mathrm{CH}_{3} \mathrm{CN}$ and passed through a silica plug. To the filtrate was added 1,3,5-trimethoxybenzene. Solvent was removed in vacuo and the residue was analyzed by ${ }^{1} \mathrm{H}$ NMR in $\mathrm{CDCl}_{3}$.

Table S1. NMR yields for aerobic oxidation of $1(0.1 \mathrm{mmol})$ by TEMPO/cocatalyst systems. Yields determined by integration values relative to $1,3,5$-trimethoxybenzene standard (relaxation time $=25 \mathrm{sec}$ ).

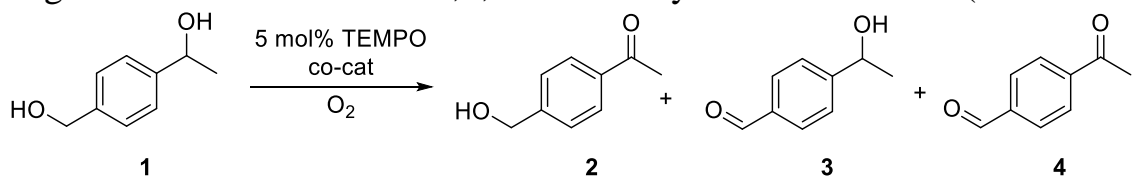

\begin{tabular}{ccccccc}
\hline Co-Catalyst & $\begin{array}{c}\text { Reaction } \\
\text { Time }(\mathrm{h})\end{array}$ & $\begin{array}{c}\text { Mass Balance } \\
(\%)\end{array}$ & $\begin{array}{c}\mathbf{1}(\mathrm{RSM}) \\
(\% \text { Yield })\end{array}$ & $\begin{array}{c}\mathbf{2} \text { (Ketone) } \\
(\% \text { Yield })\end{array}$ & $\begin{array}{c}\mathbf{3} \text { (Ald) } \\
\text { (\% Yield) }\end{array}$ & $\begin{array}{c}\mathbf{4}(\mathrm{Ald} / \mathrm{Ket}) \\
\text { (\% Yield) }\end{array}$ \\
\hline$[\mathrm{Cu}]$ & 2 & 93 & $<1$ & $<1$ & $\mathbf{7 7}$ & 16 \\
$\begin{array}{c}{\left[\mathrm{Fe}\left(\mathrm{NO}_{3}\right)_{3}\right],} \\
\mathrm{CH}_{3} \mathrm{CN}\end{array}$ & 6 & 105 & 31 & 28 & $\mathbf{4 1}$ & 5 \\
{$\left[\mathrm{Fe}\left(\mathrm{NO}_{3}\right)_{3}\right]$,} & 6 & 91 & 43 & 15 & $\mathbf{3 0}$ & 3 \\
$\mathrm{C}_{2} \mathrm{H}_{4} \mathrm{Cl}_{2}$ & 6 & 95 & 32 & 23 & $\mathbf{3 5}$ & 5 \\
$\mathrm{NO}_{\mathrm{x}}$ & 6 & & & & & \\
\hline
\end{tabular}

\section{Oxidation of 1-phenylhexane-1,6 diol $(5,0.1 \mathrm{mmol})$ by TEMPO/Cu:}

TEMPO (0.005 mmol), CuBr $(0.005 \mathrm{mmol}), 2,2^{\prime}$-dipyridyl $(0.005 \mathrm{mmol})$, and $\mathbf{5}(0.1 \mathrm{mmol})$ were added to a $20 \mathrm{~mm}$ culture tube with a stir bar. To the vial was added $\mathrm{CH}_{3} \mathrm{CN}(1 \mathrm{~mL})$ and $N$-methyl imidazole $(0.01$ $\mathrm{mmol})$. The reaction was stirred rapidly open to air and was followed by TLC. The reaction was diluted with diethyl ether and passed through a silica plug. To the filtrate was added 1,3,5-trimethoxybenzene. Solvent was removed in vacuo and the residue was analyzed by ${ }^{1} \mathrm{H} \mathrm{NMR}$ in $\mathrm{CDCl}_{3}$.

\section{Oxidation of 1-phenylhexane-1,6 diol $(5,0.1 \mathrm{mmol})$ by TEMPO/iron(III) nitrate in $\mathrm{CH}_{3} \mathrm{CN}$ :}

TEMPO $(0.005 \mathrm{mmol})$ and $\mathrm{Fe}\left(\mathrm{NO}_{3}\right)_{3} \bullet 9 \mathrm{H}_{2} \mathrm{O}(0.005 \mathrm{mmol})$ were added to a $20 \mathrm{~mm}$ culture tube with a stir bar. To the tube was added $\mathrm{CH}_{3} \mathrm{CN}(0.5 \mathrm{~mL})$. The solution was stirred rapidly open to air for $5 \mathrm{~min}$, after which $5(0.1 \mathrm{mmol})$ and an additional $0.5 \mathrm{~mL} \mathrm{CH}_{3} \mathrm{CN}$ was added. The culture tube was capped with an $\mathrm{O}_{2}$ balloon. The reaction was stirred rapidly and was followed by TLC. The reaction was diluted with diethyl ether and passed through a silica plug. To the filtrate was added 1,3,5-trimethoxybenzene. Solvent was removed in vacuo and the residue was analyzed by ${ }^{1} \mathrm{H} \mathrm{NMR}$ in $\mathrm{CDCl}_{3}$. 
Oxidation of 1-phenylhexane-1,6 diol $(5,0.1 \mathrm{mmol})$ by TEMPO/iron(III) nitrate in $\mathrm{C}_{2} \mathrm{H}_{4} \mathrm{Cl}_{2}$ :

TEMPO (0.005 mmol), $\mathrm{Fe}\left(\mathrm{NO}_{3}\right)_{3} \cdot 9 \mathrm{H}_{2} \mathrm{O}(0.005 \mathrm{mmol})$, and $\mathrm{KCl}(0.005 \mathrm{mmol})$ were added to a $20 \mathrm{~mm}$ culture tube with a stir bar. To the tube was added $\mathrm{C}_{2} \mathrm{H}_{4} \mathrm{Cl}_{2}(0.5 \mathrm{~mL})$. The solution was stirred rapidly open to air for $5 \mathrm{~min}$, after which $5(0.1 \mathrm{mmol})$ and $\mathrm{C}_{2} \mathrm{H}_{4} \mathrm{Cl}_{2}(0.5 \mathrm{~mL})$ was added. The culture tube was capped with an $\mathrm{O}_{2}$ balloon. The reaction was stirred rapidly and was followed by TLC. The reaction was diluted with diethyl ether and passed through a silica plug. To the filtrate was added 1,3,5-trimethoxybenzene. Solvent was removed in vacuo and the residue was analyzed by ${ }^{1} \mathrm{H} \mathrm{NMR}$ in $\mathrm{CDCl}_{3}$.

\section{Oxidation of 1-phenylhexane-1,6 diol $(5,0.1 \mathrm{mmol})$ by TEMPO/NO :}

TEMPO $(0.005 \mathrm{mmol}), \mathrm{NaNO}_{2}(0.01 \mathrm{mmol})$, and $\mathbf{5}(0.1 \mathrm{mmol})$ were added to a $20 \mathrm{~mm}$ culture tube with a stir bar. To the vial was added $0.02 \mathrm{M} \mathrm{HNO}_{3}$ in $\mathrm{CH}_{3} \mathrm{CN}(1 \mathrm{~mL})$. The culture tube was capped with an $\mathrm{O}_{2}$ balloon. The reaction was stirred rapidly and was followed by TLC. The reaction was diluted with diethyl ether and passed through a silica plug. To the filtrate was added 1,3,5-trimethoxybenzene. Solvent was removed in vacuo and the residue was analyzed by ${ }^{1} \mathrm{H} \mathrm{NMR}$ in $\mathrm{CDCl}_{3}$.

Table S2. NMR yields for the oxidation of 5 (4-(1'-hydroxyethyl)benzyl alcohol) (0.1 mmol) by TEMPO/cocatalyst systems. Yields determined by integration values relative to 1,3,5-trimethoxybenzene standard (relaxation delay $=25 \mathrm{~s}$ ).

\begin{tabular}{|c|c|c|c|c|c|c|}
\hline & 5 & $\underset{\frac{\mathrm{O}_{2}}{\left[\begin{array}{c}\mathrm{mol} \% \mathrm{TEMMPO} \\
{[\mathrm{co}-\mathrm{cat}]}\end{array}\right.}}{\longrightarrow}$ & 6 & c & & 8 \\
\hline $\begin{array}{c}\text { Co- } \\
\text { Catalyst }\end{array}$ & $\begin{array}{l}\text { Reaction } \\
\text { Time (h) }\end{array}$ & $\begin{array}{c}\text { Mass Balance } \\
(\%)\end{array}$ & $\begin{array}{c}5 \text { (RSM) } \\
\text { (\% Yield) }\end{array}$ & $\begin{array}{c}\text { 6 (Ketone) } \\
\text { (\% Yield) }\end{array}$ & $\begin{array}{c}7 \text { (Ald) } \\
(\% \text { Yield })\end{array}$ & $\begin{array}{c}8 \text { (Ald/Ket) } \\
\text { (\% Yield) }\end{array}$ \\
\hline$[\mathrm{Cu}]$ & 3 & 88 & 13 & 4 & 59 & 12 \\
\hline $\begin{array}{c}{\left[\mathrm{Fe}\left(\mathrm{NO}_{3}\right)_{3}\right]} \\
\mathrm{CH}_{3} \mathrm{CN}\end{array}$ & 24 & 90 & 37 & 49 & 2 & 2 \\
\hline $\begin{array}{c}{\left[\mathrm{Fe}\left(\mathrm{NO}_{3}\right)_{3}\right],} \\
\mathrm{C}_{2} \mathrm{H}_{4} \mathrm{Cl}_{2}\end{array}$ & 24 & 93 & 67 & 20 & 4 & 2 \\
\hline $\mathrm{NO}_{\mathrm{x}}$ & 24 & 99 & 28 & 62 & 4 & 5 \\
\hline
\end{tabular}

\section{Alcohol Oxidation Protocols}

\section{Oxidation of 4-(1'-hydroxyethyl)benzyl alcohol (1) by TEMPO/Cu: ${ }^{4}$}

To a solution of $1(152 \mathrm{mg}, 1 \mathrm{mmol})$ in $\mathrm{CH}_{3} \mathrm{CN}(2 \mathrm{~mL})$ in a $20 \mathrm{~mm}$ culture tube were added sequentially $\left[\mathrm{Cu}\left(\mathrm{CH}_{3} \mathrm{CN}\right)_{4}\right] \mathrm{BF}_{4}(15.7 \mathrm{mg}, 0.05 \mathrm{mmol})$, TEMPO (7.6 mg, $\left.0.05 \mathrm{mmol}\right), 2,2$ '-dipyridyl (7.8 mg, $\left.0.05 \mathrm{mmol}\right)$ with $1 \mathrm{~mL} \mathrm{CH}_{3} \mathrm{CN}$ added after each reagent $\left(5 \mathrm{~mL} \mathrm{CH}_{3} \mathrm{CN}\right.$ total). $N$-methyl imidazole $(8 \mu \mathrm{L}, 0.1 \mathrm{mmol})$ was immediately added via Hamilton syringe. The solution was stirred rapidly open to air at ambient temperature and was followed by TLC. In order to monitor the chemoselectivity of this oxidation, the reaction was quenched before 1 was fully consumed. After $1 \mathrm{~h}$, the reaction mixture was diluted with 20 $\mathrm{mL}$ of diethyl ether and filtered through a short silica plug and rinsed with additional diethyl ether. The solvent was removed in vacuo and the residue was analyzed by ${ }^{1} \mathrm{H}$ NMR spectroscopy with a 25 s relaxation delay in $\mathrm{CDCl}_{3}$ to determine the relative quantity of 1 and oxidation products. The observed ratio of 1:2:3:4 was $34: 1: 65: 1$. The residue was then purified by flash column chromatography (30\% EtOAc in pentane) to give $89.3 \mathrm{mg}$ of $\mathbf{3}$ (aldehyde) (60\% yield). 
Oxidation of 4-(1'-hydroxyethyl)benzyl alcohol (1) by TEMPO/iron(III) nitrate in $\mathrm{CH}_{3} \mathrm{CN}:{ }^{6}$

To a $20 \mathrm{~mm}$ culture tube, $\mathrm{Fe}\left(\mathrm{NO}_{3}\right)_{3} \bullet 9 \mathrm{H}_{2} \mathrm{O}(20.1 \mathrm{mg}, 0.05 \mathrm{mmol})$ and TEMPO $(7.7 \mathrm{mg}, 0.05 \mathrm{mmol})$ were added with $\mathrm{CH}_{3} \mathrm{CN}(4 \mathrm{~mL})$. The solution was stirred rapidly open to air at ambient temperature for $5 \mathrm{~min}$, after which 1 (152 mg, $1 \mathrm{mmol}$ ) was added followed by an additional $1 \mathrm{~mL}$ of $\mathrm{CH}_{3} \mathrm{CN}$ ( $5 \mathrm{~mL}$ total). The reaction was followed by TLC. After $8 \mathrm{~h}$, the reaction mixture was diluted with $20 \mathrm{~mL}$ of diethyl ether and filtered through a short silica plug and rinsed with additional diethyl ether. The solvent was removed in vacuo and the residue was analyzed by ${ }^{1} \mathrm{H}$ NMR spectroscopy with a $25 \mathrm{~s}$ relaxation delay in $\mathrm{CDCl}_{3}$ to determine the relative quantity of 1 and oxidation products. The observed ratio of 1:2:3:4 was 1:31:52:17. The residue was then purified by flash column chromatography (20-50\% EtOAc in pentane gradient) to give $43.5 \mathrm{mg}$ of $\mathbf{2}$ (ketone) (29\% yield) and $73.6 \mathrm{mg}$ of $\mathbf{3}$ (aldehyde) (49\% yield).

\section{Oxidation of 4-(1'-hydroxyethyl)benzyl alcohol (1) by TEMPO/NO $\mathbf{x}^{7}$}

To a $20 \mathrm{~mm}$ culture tube, 1 (152 mg, $1 \mathrm{mmol})$, TEMPO $(7.9 \mathrm{mg}, 0.05 \mathrm{mmol})$, and $\mathrm{NaNO}_{2}(6.8 \mathrm{mg}, 0.1$ $\mathrm{mmol})$ were added followed by $\mathrm{CH}_{3} \mathrm{CN}(5 \mathrm{~mL})$. Nitric acid $(12.6 \mu \mathrm{L}, 0.2 \mathrm{mmol})$ was added and the reaction was stirred rapidly open to air at ambient temperature and was followed by TLC. After $8 \mathrm{~h}$, the solvent was removed in vacuo and the residue was analyzed by ${ }^{1} \mathrm{H}$ NMR spectroscopy with a 25 s relaxation delay in $\mathrm{CDCl}_{3}$ to determine the relative quantity of 1 and oxidation products. The observed ratio of 1:2:3:4 was 21:29:42:8. The residue was then purified by flash column chromatography (20-50\% EtOAc in pentane gradient) to give $38.9 \mathrm{mg}$ of $\mathbf{2}$ (ketone) (26\% yield) and $61.2 \mathrm{mg}$ of $\mathbf{3}$ (aldehyde) (41\% yield).

\section{Oxidation of 1-phenylhexane-1,6 diol (5) by TEMPO/Cu: ${ }^{4}$}

To a solution of $5(195 \mathrm{mg}, 1 \mathrm{mmol})$ in $\mathrm{CH}_{3} \mathrm{CN}(2 \mathrm{~mL})$ in a $20 \mathrm{~mm}$ culture tube were added sequentially $\mathrm{CuBr}$ (7.2 mg, $0.05 \mathrm{mmol})$, TEMPO (7.6 mg, $0.05 \mathrm{mmol})$, and 2,2'-dipyridyl (7.8 $\mathrm{mg}, 0.05 \mathrm{mmol}$ ) with 1 $\mathrm{mL} \mathrm{CH} \mathrm{CH}_{3} \mathrm{CN}$ added after each reagent $\left(5 \mathrm{~mL} \mathrm{CH}_{3} \mathrm{CN}\right.$ total). $N$-methyl imidazole $(8 \mu \mathrm{L}, 0.1 \mathrm{mmol})$ was immediately added via Hamilton syringe. The solution was stirred rapidly open to air at ambient temperature and was followed by TLC. After $3 \mathrm{~h}$, the reaction mixture was diluted with $20 \mathrm{~mL}$ of diethyl ether and filtered through a short silica plug and rinsed with additional diethyl ether. The solvent was removed in vacuo and the residue was analyzed by ${ }^{1} \mathrm{H}$ NMR spectroscopy with a 25 s relaxation delay in $\mathrm{CDCl}_{3}$ to determine the relative quantity of 5 and oxidation products. The observed ratio of 5:6:7:8 was $8: 5: 68: 21$. The residue was then purified by flash column chromatography (30-100\% EtOAc in pentane gradient) to give $108.8 \mathrm{mg}$ of 7 (aldehyde) (56\% yield).

\section{Oxidation of 1-phenylhexane-1,6 diol (5) by TEMPO/iron(III) nitrate in $\mathrm{CH}_{3} \mathrm{CN}$ : $^{6}$}

To a $20 \mathrm{~mm}$ culture tube, $\mathrm{Fe}\left(\mathrm{NO}_{3}\right)_{3} \bullet 9 \mathrm{H}_{2} \mathrm{O}(20.0 \mathrm{mg}, 0.05 \mathrm{mmol})$ and TEMPO $(7.8 \mathrm{mg}, 0.05 \mathrm{mmol})$ were added with $\mathrm{CH}_{3} \mathrm{CN}(4 \mathrm{~mL})$. The solution was stirred rapidly open to air at ambient temperature for $5 \mathrm{~min}$, after which 5 (195 mg, $1 \mathrm{mmol}$ ) was added followed by an additional $1 \mathrm{~mL}$ of $\mathrm{CH}_{3} \mathrm{CN}$ ( $5 \mathrm{~mL}$ total). The reaction was capped with a septum and a balloon containing $\mathrm{O}_{2}$ and was followed by TLC. After $12 \mathrm{~h}$, the reaction mixture was diluted with $20 \mathrm{~mL}$ of diethyl ether and filtered through a short silica plug and rinsed with additional diethyl ether. The solvent was removed in vacuo and the residue was analyzed by ${ }^{1} \mathrm{H}$ NMR spectroscopy with a $25 \mathrm{~s}$ relaxation delay in $\mathrm{CDCl}_{3}$ to determine the relative quantity of $\mathbf{5}$ and various oxidation products. The observed ratio of 5:6:7:8 was 36:63:1:1. The residue was then purified by flash column chromatography (30-100\% EtOAc in pentane gradient) to give $103 \mathrm{mg}$ of $\mathbf{6}$ (ketone) (49\% yield).

\section{Oxidation of 1-phenylhexane-1,6 diol (5) by TEMPO/NO ${ }^{7}{ }^{7}$}

To a $20 \mathrm{~mm}$ culture tube, 5 (195 mg, $1 \mathrm{mmol})$, TEMPO $(7.7 \mathrm{mg}, 0.05 \mathrm{mmol})$, and $\mathrm{NaNO}_{2}(7.1 \mathrm{mg}, 0.1$ $\mathrm{mmol})$ were added followed by $\mathrm{CH}_{3} \mathrm{CN}(5 \mathrm{~mL})$. Nitric acid $(12.6 \mu \mathrm{L}, 0.2 \mathrm{mmol})$ was added and the reaction was capped with a septum and a balloon containing $\mathrm{O}_{2}$. The reaction was stirred rapidly at ambient temperature and was followed by TLC. After $24 \mathrm{~h}$, the solvent was removed in vacuo and the residue was analyzed by ${ }^{1} \mathrm{H} \mathrm{NMR}$ spectroscopy with a $25 \mathrm{~s}$ relaxation delay in $\mathrm{CDCl}_{3}$ to determine the relative quantity of 5 and oxidation products. The observed ratio of 5:6:7:8 was 60:39:1:1. The residue was then purified by 
flash column chromatography (30-100\% EtOAc in pentane gradient) to give $53.7 \mathrm{mg}$ of $\mathbf{6}$ (ketone) (28\% yield),

Oxidation of 4-quinoylmethanol (9) by TEMPO/Cu: ${ }^{4}$

To a solution of $9(159 \mathrm{mg}, 1 \mathrm{mmol})$ in $\mathrm{CH}_{3} \mathrm{CN}(2 \mathrm{~mL})$ in a $20 \mathrm{~mm}$ culture tube were added sequentially $\left[\mathrm{Cu}\left(\mathrm{CH}_{3} \mathrm{CN}\right)_{4}\right] \mathrm{BF}_{4}(15.6 \mathrm{mg}, 0.05 \mathrm{mmol})$, TEMPO (7.6 mg, $\left.0.05 \mathrm{mmol}\right)$, and 2,2'-dipyridyl (7.8 $\mathrm{mg}, 0.05$ mmol) with $1 \mathrm{~mL} \mathrm{CH}_{3} \mathrm{CN}$ added after each reagent $\left(5 \mathrm{~mL} \mathrm{CH}_{3} \mathrm{CN}\right.$ total). $N$-methyl imidazole ( $8 \mu \mathrm{L}, 0.1$ mmol) was then added via Hamilton syringe. The solution was stirred rapidly open to air at ambient temperature and was followed by TLC. After $3 \mathrm{~h}$, the reaction mixture was diluted with diethyl ether and transferred to a 6-dram vial. The solvent was removed in vacuo, and the residue was purified by flash column chromatography (0-10\% $\mathrm{MeOH}$ in $\mathrm{CH}_{2} \mathrm{Cl}_{2}$ gradient) to give $138.9 \mathrm{mg}$ of $\mathbf{1 0}$ (aldehyde) ( $88 \%$ yield).

\section{Oxidation of 4-quinoylmethanol (9) by TEMPO/iron(III) nitrate in $\mathrm{CH}_{3} \mathbf{C N}$ : $^{6}$}

To a $20 \mathrm{~mm}$ culture tube, $\mathrm{Fe}\left(\mathrm{NO}_{3}\right)_{3} \cdot 9 \mathrm{H}_{2} \mathrm{O}(20.0 \mathrm{mg}, 0.05 \mathrm{mmol})$ and TEMPO $(7.8 \mathrm{mg}, 0.05 \mathrm{mmol})$ was added with $\mathrm{CH}_{3} \mathrm{CN}(4 \mathrm{~mL})$. The solution was stirred rapidly open to air at ambient temperature for $5 \mathrm{~min}$, after which 9 (159 mg, $1 \mathrm{mmol}$ ) was added followed by an additional $1 \mathrm{~mL}$ of $\mathrm{CH}_{3} \mathrm{CN}$ (5 mL total). The reaction was capped with a septum and a balloon containing $\mathrm{O}_{2}$ and was followed by TLC. After $24 \mathrm{~h}$, no significant oxidation products were observed, and the reaction mixture was diluted with diethyl ether and transferred to a 6-dram vial. The solvent was removed in vacuo. The residue was then purified by flash column chromatography $\left(2-10 \% \mathrm{MeOH}\right.$ in $\mathrm{CH}_{2} \mathrm{Cl}_{2}$ gradient) to give $128.4 \mathrm{mg}$ of recovered 9 (81\% recovery).

\section{Oxidation of 4-quinoylmethanol (9) by TEMPO/iron(III) nitrate in $\mathrm{Cl}_{2} \mathrm{C}_{2} \mathrm{H}_{4}$ : $^{8}$}

To a $20 \mathrm{~mm}$ culture tube, $\mathrm{Fe}\left(\mathrm{NO}_{3}\right)_{3} \cdot 9 \mathrm{H}_{2} \mathrm{O}(20.0 \mathrm{mg}, 0.05 \mathrm{mmol})$, TEMPO $(7.8 \mathrm{mg}, 0.05 \mathrm{mmol})$, and $\mathrm{KCl}$ ( $3.9 \mathrm{mg}, 0.05 \mathrm{mmol}$ ) was added with $\mathrm{C}_{2} \mathrm{H}_{4} \mathrm{Cl}_{2}(4 \mathrm{~mL})$. The solution was stirred rapidly open to air at ambient temperature for $5 \mathrm{~min}$, after which $9(159 \mathrm{mg}, 1 \mathrm{mmol})$ was added followed by an additional $1 \mathrm{~mL}$ of $\mathrm{C}_{2} \mathrm{H}_{4} \mathrm{Cl}_{2}$ (5 mL total). The reaction was capped with a septum and a balloon containing $\mathrm{O}_{2}$ and was followed by TLC. After $24 \mathrm{~h}$, no significant oxidation products were observed, and the reaction mixture was diluted with diethyl ether and transferred to a 6-dram vial. The solvent was removed in vacuo. The residue was then purified by flash column chromatography $\left(2-10 \% \mathrm{MeOH}\right.$ in $\mathrm{CH}_{2} \mathrm{Cl}_{2}$ gradient) to give $147.9 \mathrm{mg}$ of recovered 9 (93\% recovery).

\section{Oxidation of 2-amino benzyl alcohol (11) by TEMPO/Cu: ${ }^{4}$}

To a solution of $11(124 \mathrm{mg}, 1 \mathrm{mmol})$ in $\mathrm{CH}_{3} \mathrm{CN}(2 \mathrm{~mL})$ in a $20 \mathrm{~mm}$ culture tube were added sequentially $\left[\mathrm{Cu}\left(\mathrm{CH}_{3} \mathrm{CN}\right)_{4}\right] \mathrm{BF}_{4}(15.7 \mathrm{mg}, 0.05 \mathrm{mmol})$, TEMPO (7.6 mg, $\left.0.05 \mathrm{mmol}\right), 2,2^{\prime}$-dipyridyl $(7.8 \mathrm{mg}, 0.05 \mathrm{mmol})$ with $1 \mathrm{~mL} \mathrm{CH}_{3} \mathrm{CN}$ added after each reagent $\left(5 \mathrm{~mL} \mathrm{CH}_{3} \mathrm{CN}\right.$ total). $N$-methyl imidazole $(8 \mu \mathrm{L}, 0.1 \mathrm{mmol})$ was immediately added via Hamilton syringe. The solution was stirred rapidly open to air at ambient temperature and was followed by TLC. After $3 \mathrm{~h}$, the reaction mixture was diluted with $20 \mathrm{~mL}$ of diethyl ether and filtered through a short silica plug. The solvent was removed in vacuo and the residue was then purified by flash column chromatography (20\% EtOAc in pentane) to give $113 \mathrm{mg}$ of $\mathbf{1 2}$ (aldehyde) (93\% yield).

\section{Oxidation of 2-amino benzyl alcohol (11) by TEMPO/iron(III) nitrate in $\mathrm{CH}_{3} \mathbf{C N}$ : $^{6}$}

To a $20 \mathrm{~mm}$ culture tube, $\mathrm{Fe}\left(\mathrm{NO}_{3}\right)_{3} \bullet 9 \mathrm{H}_{2} \mathrm{O}(20.0 \mathrm{mg}, 0.05 \mathrm{mmol})$ and TEMPO $(7.8 \mathrm{mg}, 0.05 \mathrm{mmol})$ was added with $\mathrm{CH}_{3} \mathrm{CN}(4 \mathrm{~mL})$. The solution was stirred rapidly open to air at ambient temperature for $5 \mathrm{~min}$, after which 11 (123 mg, $1 \mathrm{mmol}$ ) was added followed by an additional $1 \mathrm{~mL}$ of $\mathrm{CH}_{3} \mathrm{CN}$ (5 mL total). The reaction was capped with a septum and a balloon containing $\mathrm{O}_{2}$ and was followed by TLC. After $12 \mathrm{~h}$, the reaction mixture was diluted with $20 \mathrm{~mL}$ of diethyl ether and filtered through a short silica plug. The solvent was removed in vacuo, and the residue was then purified by flash column chromatography (0-100\% EtOAc in pentane gradient) to give $81.9 \mathrm{mg}$ of recovered 11 (67\% recovery). 
Oxidation of 2-amino benzyl alcohol (11) by TEMPO/iron(III) nitrate in $\mathrm{Cl}_{2} \mathrm{C}_{2} \mathrm{H}_{4}$ : $^{\mathbf{8}}$

To a $20 \mathrm{~mm}$ culture tube, $\mathrm{Fe}\left(\mathrm{NO}_{3}\right)_{3} \cdot 9 \mathrm{H}_{2} \mathrm{O}(20.0 \mathrm{mg}, 0.05 \mathrm{mmol})$, TEMPO (7.8 mg, $\left.0.05 \mathrm{mmol}\right)$, and $\mathrm{KCl}$ ( $3.9 \mathrm{mg}, 0.05 \mathrm{mmol}$ ) was added with $\mathrm{C}_{2} \mathrm{H}_{4} \mathrm{Cl}_{2}(4 \mathrm{~mL})$. The solution was stirred rapidly open to air at ambient temperature for $5 \mathrm{~min}$, after which $11(123 \mathrm{mg}, 1 \mathrm{mmol})$ was added followed by an additional $1 \mathrm{~mL}$ of $\mathrm{C}_{2} \mathrm{H}_{4} \mathrm{Cl}_{2}$ (5 mL total). The reaction was capped with a septum and a balloon containing $\mathrm{O}_{2}$ and was followed by TLC. After $24 \mathrm{~h}$, no significant oxidation products were observed, and the reaction mixture was diluted with diethyl ether and transferred to a 6-dram vial. The solvent was removed in vacuo. The solvent was removed in vacuo, and the residue was then purified by flash column chromatography (0-100\% EtOAc in pentane gradient) to give $94.3 \mathrm{mg}$ of recovered $\mathbf{1 1}$ ( $77 \%$ recovery).

\section{Oxidation of 4-pentyn-1-ol (13) by TEMPO/Cu:}

To a solution of 4-pentyn-1-ol (86 mg, $1 \mathrm{mmol})$ in $\mathrm{CH}_{3} \mathrm{CN}(2 \mathrm{~mL})$ in a $20 \mathrm{~mm}$ culture tube were added sequentially $\left[\mathrm{Cu}\left(\mathrm{CH}_{3} \mathrm{CN}\right)_{4}\right] \mathrm{BF}_{4}(15.7 \mathrm{mg}, 0.05 \mathrm{mmol})$, TEMPO $(7.8 \mathrm{mg}, 0.05 \mathrm{mmol})$, and 2,2'-dipyridyl ( $7.8 \mathrm{mg}, 0.05 \mathrm{mmol}$ ) with $1 \mathrm{~mL} \mathrm{CH}_{3} \mathrm{CN}$ added after each reagent ( $5 \mathrm{~mL} \mathrm{CH}_{3} \mathrm{CN}$ total). $N$-methyl imidazole $(8 \mu \mathrm{L}, 0.1 \mathrm{mmol})$ was then added via Hamilton syringe. The reaction was capped with a septum and a balloon containing $\mathrm{O}_{2}$ and was followed by TLC. After $3 \mathrm{~h}$, the reaction mixture was diluted with $20 \mathrm{~mL}$ diethyl ether. The solution filtered through a short silica plug. The solvent was removed in vacuo at $0{ }^{\circ} \mathrm{C}$, and the unpurified residue was analyzed by ${ }^{1} \mathrm{H}$ NMR spectroscopy in $\mathrm{CDCl}_{3}$, revealing a mixture of 4pentynal, a dialdehyde product arising from alkyne $\mathrm{C}-\mathrm{H}$ coupling (confirmed by HRMS), and unreacted starting material in a ratio of ca. 6.5:7.5:1. No acid product is observed. No attempt was made to isolate the product mixture. When the above experiment was repeated under air, 13 underwent conversion. No products derived from 13 could be observed by ${ }^{1} \mathrm{H}$ NMR, however, indicating substrate decomposition, which has been observed previously. ${ }^{4}$

\section{Oxidation of 4-pentyn-1-ol (13) by TEMPO/iron(III) nitrate in $\mathrm{Cl}_{2} \mathbf{C}_{2} \mathbf{H} 4$ :}

To a $20 \mathrm{~mm}$ culture tube, $\mathrm{Fe}\left(\mathrm{NO}_{3}\right)_{3} \cdot 9 \mathrm{H}_{2} \mathrm{O}(40.0 \mathrm{mg}, 0.1 \mathrm{mmol})$, TEMPO (15.6 mg, $\left.0.1 \mathrm{mmol}\right)$, and $\mathrm{KCl}(6$ $\mathrm{mg}, 0.1 \mathrm{mmol}$ ) was added with $\mathrm{C}_{2} \mathrm{H}_{4} \mathrm{Cl}_{2}(4 \mathrm{~mL})$. The solution was stirred rapidly open to air at ambient temperature for $5 \mathrm{~min}$, after which 4-pentyn-1-ol $13(95 \mu \mathrm{L}, 1 \mathrm{mmol})$ was added via Hamilton syringe followed by an additional $1 \mathrm{~mL}$ of $\mathrm{C}_{2} \mathrm{H}_{4} \mathrm{Cl}_{2}(5 \mathrm{~mL}$ total). The reaction was capped with a septum and a balloon containing $\mathrm{O}_{2}$ and was followed by TLC. After $24 \mathrm{~h}$ the reaction mixture was diluted with $20 \mathrm{~mL}$ diethyl passed through a silica plug. The solvent was removed in vacuo. The residue was analyzed by ${ }^{1} \mathrm{H}$ NMR which demonstrated $<5 \%$ aldehyde product 14 present relative to the acid product 15 . The residue was purified by flash column chromatography $\left(0-9 \% \mathrm{MeOH}\right.$ in $\mathrm{CH}_{2} \mathrm{Cl}_{2}$ gradient) to give $70.3 \mathrm{mg}$ of 15 (72\% yield).

\section{Chemoselectivity of Related $\mathrm{M}\left(\mathrm{NO}_{3}\right)_{\mathrm{x}}$ Systems}

Variations on the $\mathrm{Fe}\left(\mathrm{NO}_{3}\right)_{3} / \mathrm{TEMPO}$ cocatalyst system for aerobic alcohol oxidation have been reported, including a $\mathrm{Fe}\left(\mathrm{NO}_{3}\right)_{3} / 2,2^{\prime}$-bipyridine/TEMPO system in acetic acid ${ }^{9}$ and a $\mathrm{Cu}\left(\mathrm{NO}_{3}\right)_{2} / \mathrm{TEMPO}$ system. ${ }^{10}$ To complement the studies presented in Fig. 4 of the main text, we examined the chemoselectivity of these systems for aerobic alcohol oxidation.

We first examined the aerobic oxidation of $\mathbf{5}$ under conditions derived from the original reports. ${ }^{9}{ }^{10}$ Results are summarized in Table S3. The TEMPO/Fe( $\left(\mathrm{NO}_{3}\right)_{3} / \mathrm{bpy}$ system showed moderate chemoselectivity for oxidation of the $1^{\circ}$ aliphatic alcohol group. The TEMPO/Cu(NO$\left.)_{3}\right)_{2}$ system instead showed greater selectivity for oxidation of the $2^{\circ}$ benzylic alcohol, albeit with slower overall reactivity.

$\mathrm{TEMPO} / \mathrm{Fe}\left(\mathrm{NO}_{3}\right)_{3} / \mathrm{bpy}$

To a $20 \mathrm{~mm}$ culture tube was added TEMPO $(0.01 \mathrm{mmol}), \mathrm{Fe}\left(\mathrm{NO}_{3}\right)_{3} \cdot 9 \mathrm{H}_{2} \mathrm{O}(0.01 \mathrm{mmol})$, and 2,2'-bpy $(0.01$ $\mathrm{mmol})$ with a stir bar. Acetic acid $(0.75 \mathrm{~mL})$ was added, and the solution was stirred rapidly (1000 RPM) 
open to air for $5 \mathrm{~min}$, after which $5(0.2 \mathrm{mmol})$ with an additional $0.25 \mathrm{~mL}$ acetic acid to rinse the walls of the tube. The tube was kept open to ambient air during the reaction. After $6 \mathrm{~h}$, the reaction was diluted with ethyl acetate and 1,3,5-trimethoxybenzene was added. The solution was passed through a short silica plug. Solvent was removed in vacuo and the residue was analyzed by ${ }^{1} \mathrm{H} \mathrm{NMR}$ in $\mathrm{CDCl}_{3}$.

\section{$\mathrm{TEMPO} / \mathrm{Cu}\left(\mathrm{NO}_{3}\right)_{2}$}

To a 1.5-dram vial was added TEMPO (0.02 mmol), $\mathrm{Cu}\left(\mathrm{NO}_{3}\right)_{2} \cdot 2.5\left(\mathrm{H}_{2} \mathrm{O}\right)(0.02 \mathrm{mmol})$, and $5(0.2 \mathrm{mmol})$ with a stir bar and $1 \mathrm{~mL}$ 1,2-dichloroethane or $\mathrm{CH}_{3} \mathrm{CN}$. The vial was capped with a septum pierced with a needle attached to a balloon of $\mathrm{O}_{2}$. After $24 \mathrm{~h}$, the reaction was diluted with diethyl ether and 1,3,5trimethoxybenzene was added. The solution was passed through a short silica plug. Solvent was removed in vacuo and the residue was analyzed by ${ }^{1} \mathrm{H}$ NMR.

Table S3. NMR yields for the oxidation of 5 (4-(1'-hydroxyethyl)benzyl alcohol) $(0.2 \mathrm{mmol})$ by $\mathrm{TEMPO} / \mathrm{Fe}\left(\mathrm{NO}_{3}\right)_{3} / \mathrm{bpy}$ and TEMPO/Cu(NO$\left.)_{2}\right)_{2}$ systems. Yields determined by integration values relative to 1,3,5-trimethoxybenzene standard (relaxation delay $=25 \mathrm{~s}$ ).

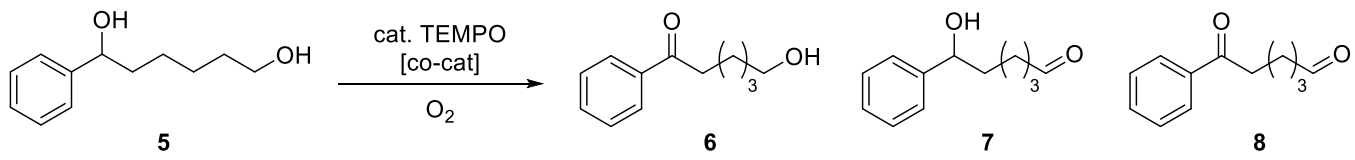

\begin{tabular}{ccccccc}
\hline Co-Catalyst & $\begin{array}{c}\text { Reaction } \\
\text { Time }(\mathrm{h})\end{array}$ & $\begin{array}{c}\text { Mass Balance } \\
(\%)\end{array}$ & $\begin{array}{c}\mathbf{5}(\mathrm{RSM}) \\
(\% \text { Yield })\end{array}$ & $\begin{array}{c}\mathbf{6} \text { (Ketone) } \\
\text { (\% Yield) }\end{array}$ & $\begin{array}{c}\mathbf{7}(\mathrm{Ald}) \\
(\% \text { Yield })\end{array}$ & $\begin{array}{c}\mathbf{8}(\mathrm{Ald} / \mathrm{Ket}) \\
\text { (\% Yield) }\end{array}$ \\
\hline $\mathrm{Cu}\left(\mathrm{NO}_{3}\right)_{2}, \mathrm{CH}_{3} \mathrm{CN}$ & 24 & 87 & 70 & 15 & 2 & trace \\
$\mathrm{Cu}\left(\mathrm{NO}_{3}\right)_{2}, \mathrm{DCE}$ & 24 & 85 & 68 & 15 & 2 & trace \\
$\mathrm{Fe}\left(\mathrm{NO}_{3}\right)_{3} / \mathrm{bpy}$ & 6 & 86 & 34 & 14 & 27 & 11 \\
\hline
\end{tabular}

We also followed the aerobic oxidation of cyclohexane $\left(2^{\circ}\right.$ aliphatic alcohol) and cyclohexylmethanol $\left(1^{\circ}\right.$ aliphatic alcohol) by these systems.

$\mathrm{TEMPO} / \mathrm{Fe}\left(\mathrm{NO}_{3}\right)_{3} / \mathrm{bpy}$

To a 1.5-dram vial was added $\mathrm{Fe}\left(\mathrm{NO}_{3}\right)_{3} \cdot 9 \mathrm{H}_{2} \mathrm{O}(0.01 \mathrm{mmol})$ with a stir bar. To the vial was added $0.5 \mathrm{~mL}$ of a stock solution containing TEMPO $(20 \mathrm{mM})$ and 2,2'-bpy $(20 \mathrm{mM})$ in acetic acid. The solution was stirred open to air. After $5 \mathrm{~min}, 0.5 \mathrm{~mL}$ of a stock solution containing cyclohexanol $(200 \mathrm{mM})$ or cyclohexylmethanol $(200 \mathrm{mM})$ with a known amount of $\mathrm{PhBr}$ in acetic acid was added. The vial was capped with a septum pierced with a needle attached to a balloon of $\mathrm{O}_{2}$. At given times, $40 \mu \mathrm{L}$ aliquots were withdrawn from the reaction solution, filtered through a short $\mathrm{SiO}_{2}$ plug, rinsed with ca. $2 \mathrm{~mL} \mathrm{CH}_{3} \mathrm{CN}$, and analyzed by GC. For the cyclohexanol reaction, the peak in the GC associated with cyclohexanol was obscured by acetic acid, but the peaks for cyclohexanone and $\mathrm{PhBr}$ were well resolved. Conditions: $60{ }^{\circ} \mathrm{C}$, hold $1 \mathrm{~min}$, then $60{ }^{\circ} \mathrm{C}$ to $200{ }^{\circ} \mathrm{C}, 20 \mathrm{deg} / \mathrm{min}$. Retention times: $\mathrm{PhBr}, 4.7 \mathrm{~min}$; cyclohexanol, $5.1 \mathrm{~min}$; cyclohexanone, $4.4 \mathrm{~min}$; cyclohexylmethanol, $6.1 \mathrm{~min}$; cyclohexane carboxaldehyde, $4.2 \mathrm{~min}$.

For the oxidation of cyclohexylmethanol, a $3 \mathrm{~h}$ induction period is observed during which the rate of cyclohexanemethanol conversion is approximately equal to the conversion of cyclohexanol over the same time (Fig. S11). However, after this induction period, the rate of cyclohexanemethanol conversion increases while that of cyclohexanol is unchanged.

$\mathrm{TEMPO} / \mathrm{Cu}\left(\mathrm{NO}_{3}\right)_{2}$

To a 1.5-dram vial was added TEMPO $(0.01 \mathrm{mmol}), \mathrm{Cu}\left(\mathrm{NO}_{3}\right)_{2} \cdot 2.5\left(\mathrm{H}_{2} \mathrm{O}\right)(0.01 \mathrm{mmol})$, a stir bar and $1 \mathrm{~mL}$ of a stock solution containing cyclohexanol $(100 \mathrm{mM})$ or cyclohexylmethanol $(100 \mathrm{mM})$ with a known 
amount of $\mathrm{PhBr}$ in DCE. The vial was capped with a septum pierced with a needle attached to a balloon of $\mathrm{O}_{2}$. At given times, $40 \mu \mathrm{L}$ aliquots were withdrawn from the reaction solution, filtered through a short $\mathrm{SiO}_{2}$ plug, rinsed with ca. $2 \mathrm{~mL} \mathrm{CH}_{3} \mathrm{CN}$, and analyzed by $\mathrm{GC}$.

In this system, conversion of cyclohexanol is observed to be more rapid than conversion of cyclohexanemethanol (Fig. S12).
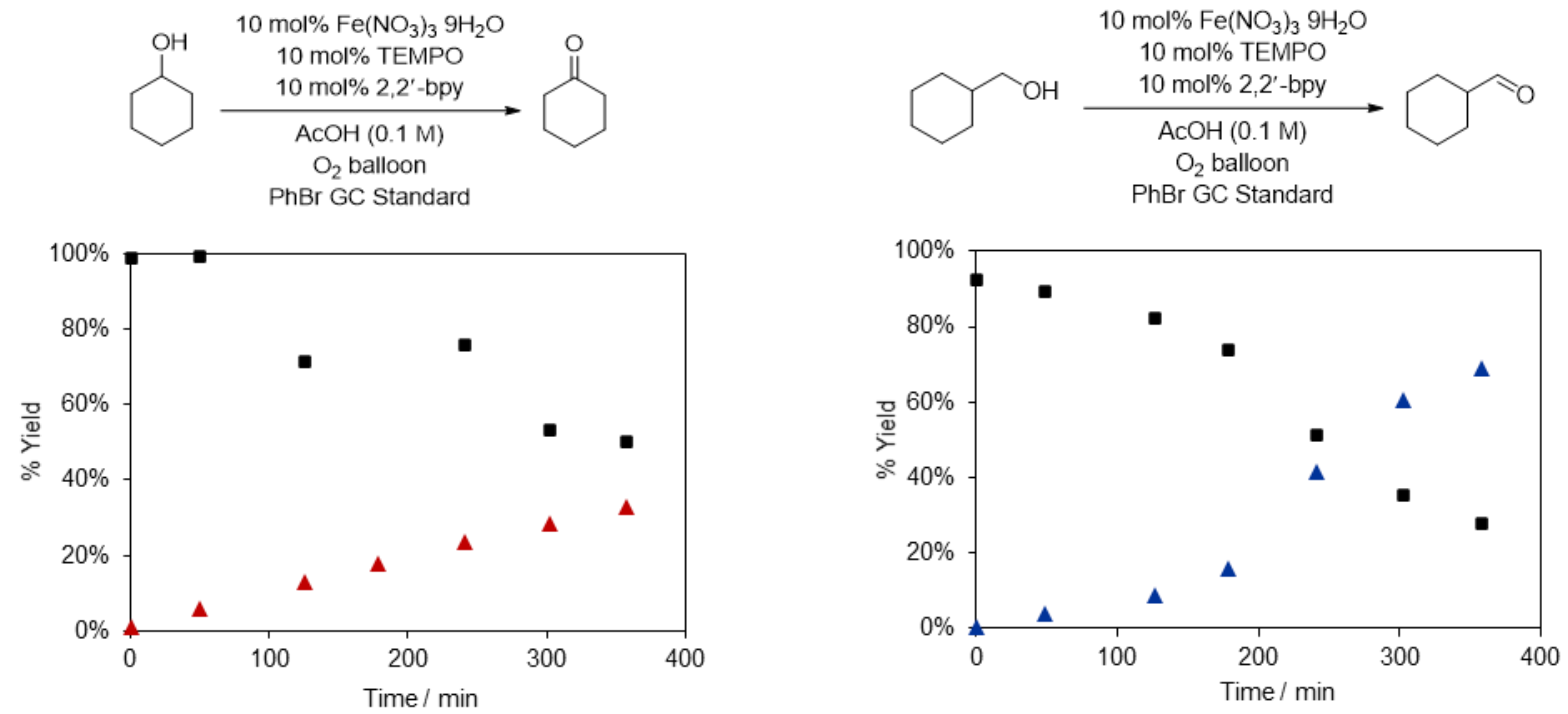

Figure S11. Time courses for the $\mathrm{Fe}\left(\mathrm{NO}_{3}\right)_{3} /$ bpy/TEMPO cocatalyzed aerobic oxidation of cyclohexanol and cyclohexylmethanol. Monitored by GC with $\mathrm{PhBr}$ internal standard.
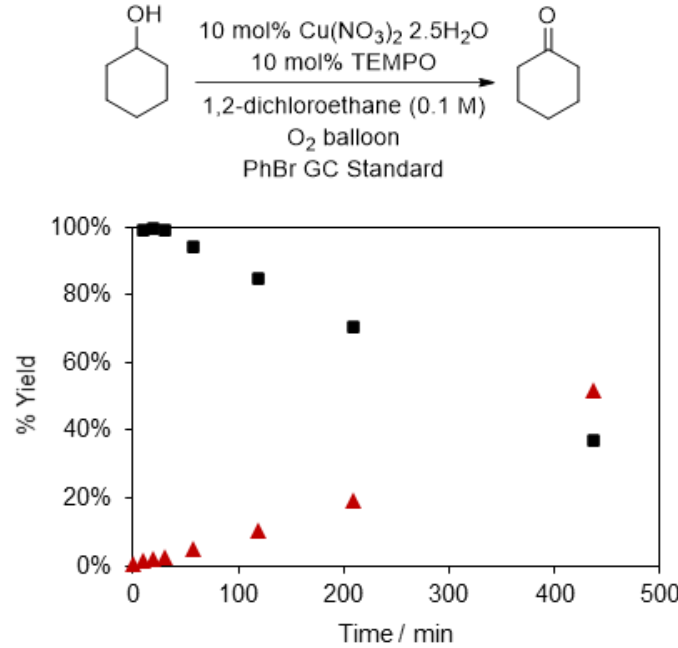
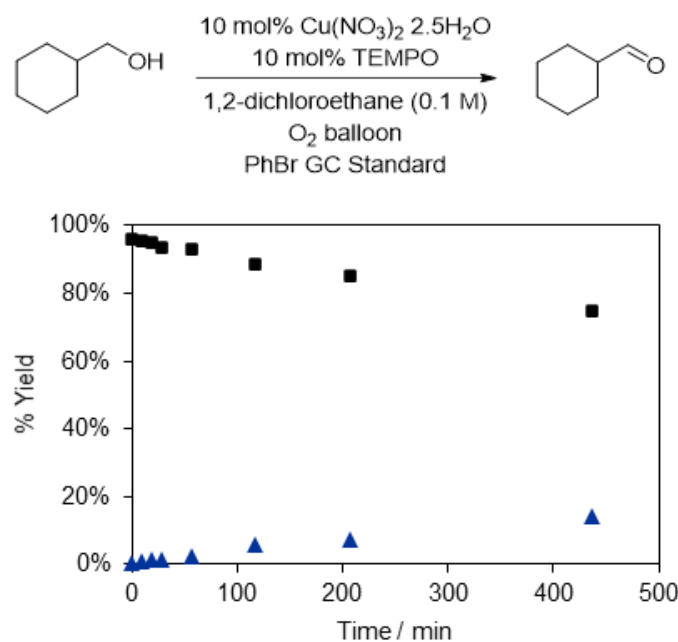

Figure S12. Time courses for the $\mathrm{Cu}\left(\mathrm{NO}_{3}\right)_{2} / \mathrm{TEMPO}$ cocatalyzed aerobic oxidation of cyclohexanol and cyclohexylmethanol. Monitored by $\mathrm{GC}$ with $\mathrm{PhBr}$ internal standard. 


\section{Characterization of Alcohol Oxidation Products}<smiles>CC(=O)c1ccc(CO)cc1</smiles>

4-(Hydroxymethyl)acetophenone (2). Colorless oil. ${ }^{1} \mathrm{H}$ NMR (500 MHz, Chloroform- $d$ ) $\delta 7.93$ (d, $J=$ $8.2 \mathrm{~Hz}, 2 \mathrm{H}), 7.44$ (d, $J=8.1 \mathrm{~Hz}, 2 \mathrm{H}), 4.76(\mathrm{~s}, 2 \mathrm{H}), 2.58$ (s, 3H), 2.26 (bs, 1H). ${ }^{13} \mathrm{C}$ NMR $(126 \mathrm{MHz}$, $\left.\mathrm{CDCl}_{3}\right) \delta 198.13,146.42,136.42,128.73,126.73,64.68,26.75$. HRMS (ESI) exact mass calculated for $[\mathrm{M}+\mathrm{H}]^{+}\left(\mathrm{C}_{9} \mathrm{H}_{11} \mathrm{O}_{2}\right)$ requires $\mathrm{m} / \mathrm{z} 151.0754$, found $\mathrm{m} / \mathrm{z} 151.0753$, difference $0.7 \mathrm{ppm}$. Spectral properties are consistent with literature values. ${ }^{11}$<smiles>CC(O)c1ccc(C=O)cc1</smiles>

4-(1-hydroxyethyl)benzaldehyde (3). Colorless oil. ${ }^{1} \mathrm{H}$ NMR $(500 \mathrm{MHz}$, Chloroform- $d) \delta 9.96(\mathrm{~d}, J=$ $3.0 \mathrm{~Hz}, 1 \mathrm{H}), 7.84(\mathrm{dd}, J=8.3,2.2 \mathrm{~Hz}, 2 \mathrm{H}), 7.52(\mathrm{dd}, J=8.0,1.3 \mathrm{~Hz}, 2 \mathrm{H}), 4.97(\mathrm{q}, J=6.5 \mathrm{~Hz}, 1 \mathrm{H}), 2.35$ $(\mathrm{b}, 1 \mathrm{H}), 1.50(\mathrm{dd}, J=6.5,1.7 \mathrm{~Hz}, 3 \mathrm{H}) .{ }^{13} \mathrm{C} \mathrm{NMR}\left(126 \mathrm{MHz}, \mathrm{CDCl}_{3}\right) \delta 192.16,152.89,135.68,130.15$, $126.03,70.00,25.47$. Spectral properties are consistent with literature values. ${ }^{4,12}$<smiles>O=C(CCCCCO)c1ccccc1</smiles>

5-Hydroxypentyl phenyl ketone (6). Colorless oil. ${ }^{1} \mathrm{H}$ NMR $(500 \mathrm{MHz}$, Chloroform- $d$ ) $\delta 7.95$ (d, $J=7.2$ $\mathrm{Hz}, 2 \mathrm{H}), 7.54(\mathrm{t}, J=7.4 \mathrm{~Hz}, 1 \mathrm{H}), 7.45(\mathrm{t}, J=7.7 \mathrm{~Hz}, 2 \mathrm{H}), 3.66(\mathrm{t}, J=6.5 \mathrm{~Hz}, 2 \mathrm{H}), 2.98(\mathrm{t}, J=7.3 \mathrm{~Hz}$, $2 \mathrm{H}), 1.77(\mathrm{p}, J=7.4 \mathrm{~Hz}, 2 \mathrm{H}), 1.63(\mathrm{~m}, 3 \mathrm{H}), 1.52-1.42(\mathrm{~m}, 2 \mathrm{H}) .{ }^{13} \mathrm{C} \mathrm{NMR}\left(126 \mathrm{MHz}, \mathrm{CDCl}_{3}\right) \delta 200.52$, 137.12, 133.07, 128.68, 128.14, 62.75, 38.56, 32.61, 25.58, 24.03. HRMS (ESI) exact mass calculated for $[\mathrm{M}+\mathrm{H}]^{+}\left(\mathrm{C}_{12} \mathrm{H}_{17} \mathrm{O}_{2}\right)$ requires $\mathrm{m} / \mathrm{z} 193.1223$, found $\mathrm{m} / \mathrm{z}$ 193.1222, difference $0.5 \mathrm{ppm}$. Spectral properties are consistent with literature values. ${ }^{13}$<smiles>O=CCCCCC(O)c1ccccc1</smiles>

6-Hydroxy-6-phenyl-hexanal (7). Colorless syrup. ${ }^{1} \mathrm{H}$ NMR $(500 \mathrm{MHz}$, Chloroform- $d$ ) $\delta 9.73(\mathrm{~s}, 1 \mathrm{H})$, $7.39-7.26(\mathrm{~m}, 5 \mathrm{H}), 4.66(\mathrm{t}, J=6.6 \mathrm{~Hz}, 1 \mathrm{H}), 2.41(\mathrm{t}, J=7.3 \mathrm{~Hz}, 2 \mathrm{H}), 2.06(\mathrm{bs}, 1 \mathrm{H}), 1.88-1.77(\mathrm{~m}, 1 \mathrm{H})$, $1.77-1.60(\mathrm{~m}, 3 \mathrm{H}), 1.46(\mathrm{~s}, 1 \mathrm{H}), 1.33(\mathrm{~s}, 1 \mathrm{H}) .{ }^{13} \mathrm{C}$ NMR $\left(126 \mathrm{MHz}, \mathrm{CDCl}_{3}\right) \delta 202.70,144.76,128.62$, $127.74,125.95,74.46,43.91,38.84,25.49,22.03$. Spectral properties are consistent with literature values. $^{4}$<smiles>O=Cc1ccnc2ccccc12</smiles>

Quinoline-4-carboxaldehyde (10). Peach-colored solid. ${ }^{1} \mathrm{H}$ NMR (500 MHz, Chloroform- $d$ ) $\delta 10.52$ (s, $1 \mathrm{H}), 9.20(\mathrm{~d}, J=4.1 \mathrm{~Hz}, 1 \mathrm{H}), 9.02(\mathrm{~d}, J=9.3 \mathrm{~Hz}, 1 \mathrm{H}), 8.22(\mathrm{~d}, J=8.4 \mathrm{~Hz}, 1 \mathrm{H}), 7.83(\mathrm{t}, J=7.7 \mathrm{~Hz}, 1 \mathrm{H})$, $7.79(\mathrm{~d}, J=4.2 \mathrm{~Hz}, 1 \mathrm{H}), 7.74(\mathrm{t}, J=8.3 \mathrm{~Hz}, 1 \mathrm{H}) .{ }^{13} \mathrm{C} \mathrm{NMR}\left(126 \mathrm{MHz}, \mathrm{CDCl}_{3}\right) \delta 192.99,150.59,149.43$, 
136.90, 130.32, 130.20, 129.53, 125.94, 124.56, 124.03. HRMS (ESI) exact mass calculated for $[\mathrm{M}+\mathrm{H}]^{+}$ $\left(\mathrm{C}_{10} \mathrm{H}_{8} \mathrm{NO}\right)$ requires $\mathrm{m} / \mathrm{z} 158.0600$, found $\mathrm{m} / \mathrm{z} 158.0599$, difference $0.6 \mathrm{ppm}$. Spectral properties are consistent with literature values. ${ }^{14}$<smiles>Nc1ccccc1C=O</smiles>

2-Aminobenaldehyde (12). Yellow oil. ${ }^{1} \mathrm{H}$ NMR $(500 \mathrm{MHz}$, Chloroform- $d$ ) $\delta 9.87(\mathrm{~s}, 1 \mathrm{H}), 7.48(\mathrm{~d}, J=$ $7.8 \mathrm{~Hz}, 1 \mathrm{H}), 7.31(\mathrm{t}, J=8.5 \mathrm{~Hz}, 1 \mathrm{H}), 6.75(\mathrm{t}, J=7.4 \mathrm{~Hz}, 1 \mathrm{H}), 6.65(\mathrm{~d}, J=8.3 \mathrm{~Hz}, 1 \mathrm{H}), 6.11(\mathrm{bs}, 2 \mathrm{H}) .{ }^{13} \mathrm{C}$ NMR $\left(126 \mathrm{MHz}, \mathrm{CDCl}_{3}\right) \delta 194.19,150.01,135.85,135.32,119.02,116.53,116.15$. HRMS (ESI) exact mass calculated for $[\mathrm{M}+\mathrm{H}]^{+}\left(\mathrm{C}_{7} \mathrm{H}_{8} \mathrm{NO}\right)$ requires $\mathrm{m} / \mathrm{z} 122.0600$, found $\mathrm{m} / \mathrm{z} 122.0599$, difference $0.9 \mathrm{ppm}$. Spectral properties are consistent with literature values. ${ }^{4}$<smiles>C#CCCC(=O)O</smiles>

4-Pentynoic acid (15). White powder. ${ }^{1} \mathrm{H}$ NMR (500 MHz, Chloroform- $d$ ) $\delta 10.42$ (bs), 2.62 (t, $J=6.9$ $\mathrm{Hz}, 2 \mathrm{H}), 2.52(\mathrm{td}, J=7.7,2.6 \mathrm{~Hz}, 2 \mathrm{H}), 2.00(\mathrm{t}, J=2.6 \mathrm{~Hz}, 1 \mathrm{H}) .{ }^{13} \mathrm{C} \mathrm{NMR}\left(126 \mathrm{MHz}, \mathrm{CDCl}_{3}\right) \delta 177.76$, 82.25, 69.38, 33.27, 14.25. RMS (ESI) exact mass calculated for $[\mathrm{M}-\mathrm{H}]^{-}\left(\mathrm{C}_{5} \mathrm{H}_{5} \mathrm{O}_{2}\right)$ requires $\mathrm{m} / \mathrm{z} 97.0295$, found $\mathrm{m} / \mathrm{z}$ 97.0296, difference $1.0 \mathrm{ppm}$. 


\section{1. ${ }^{1} \mathrm{H}$ and ${ }^{13} \mathrm{C}$ NMR Spectra of Alcohol Substrates}

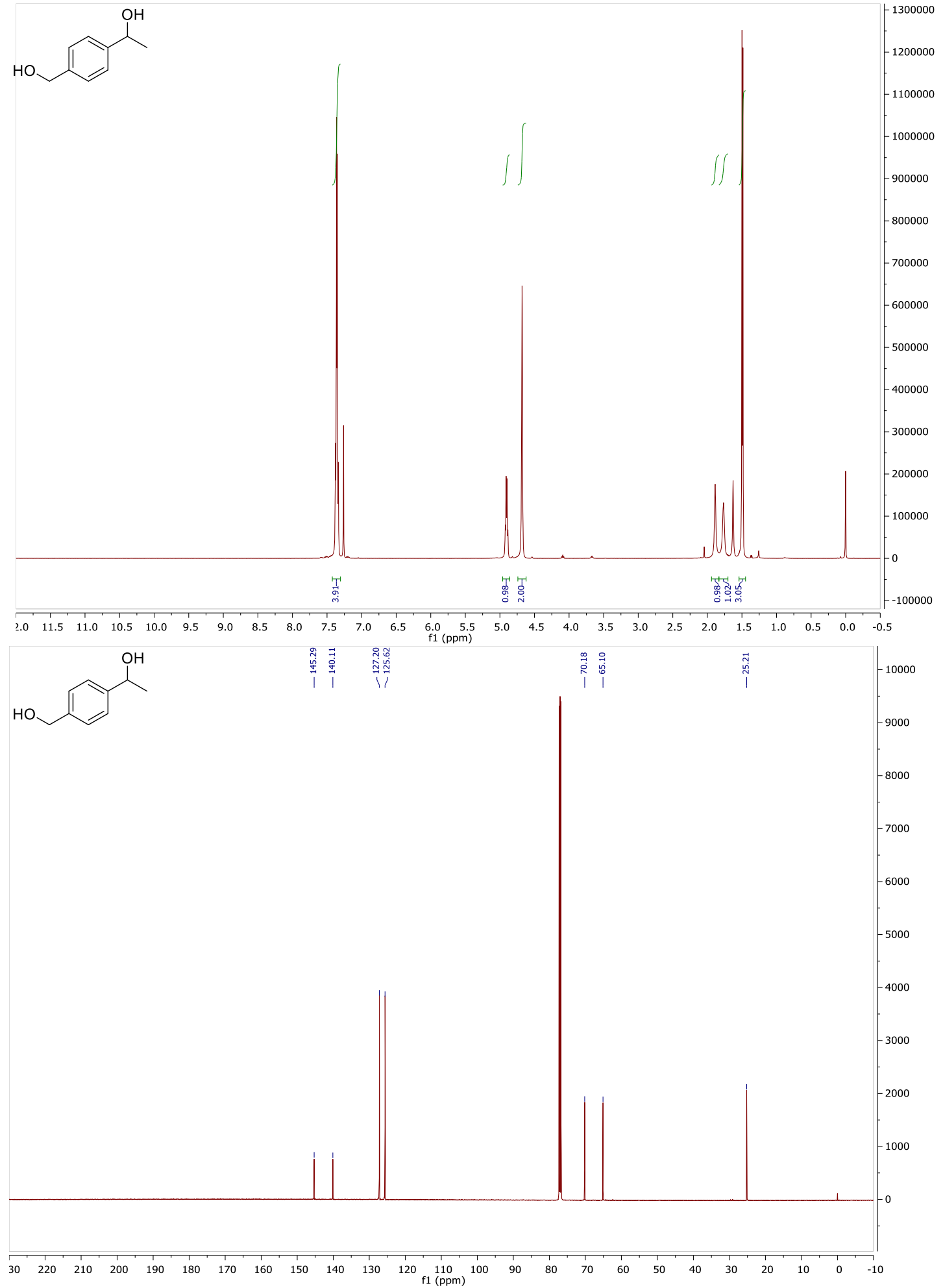




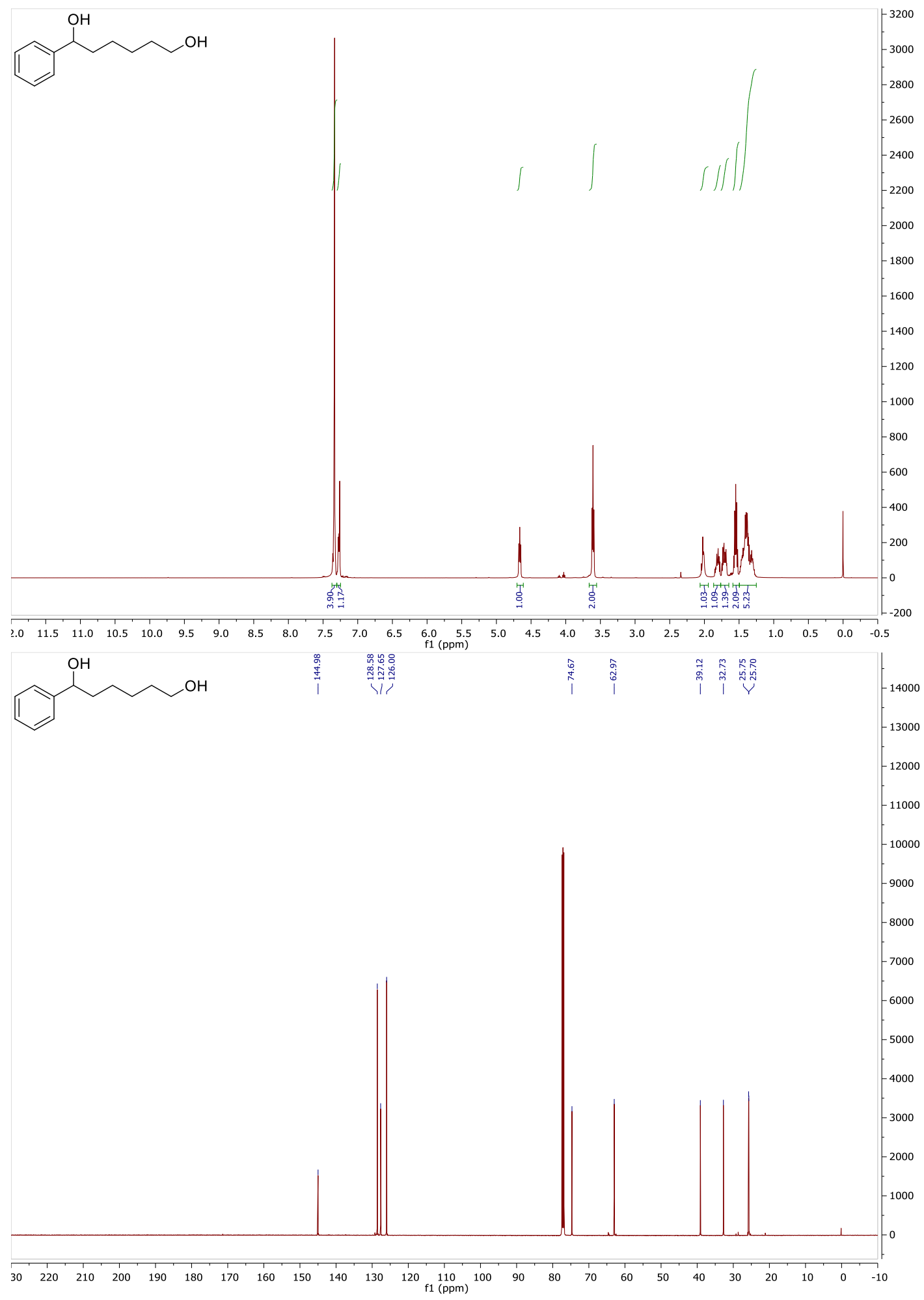



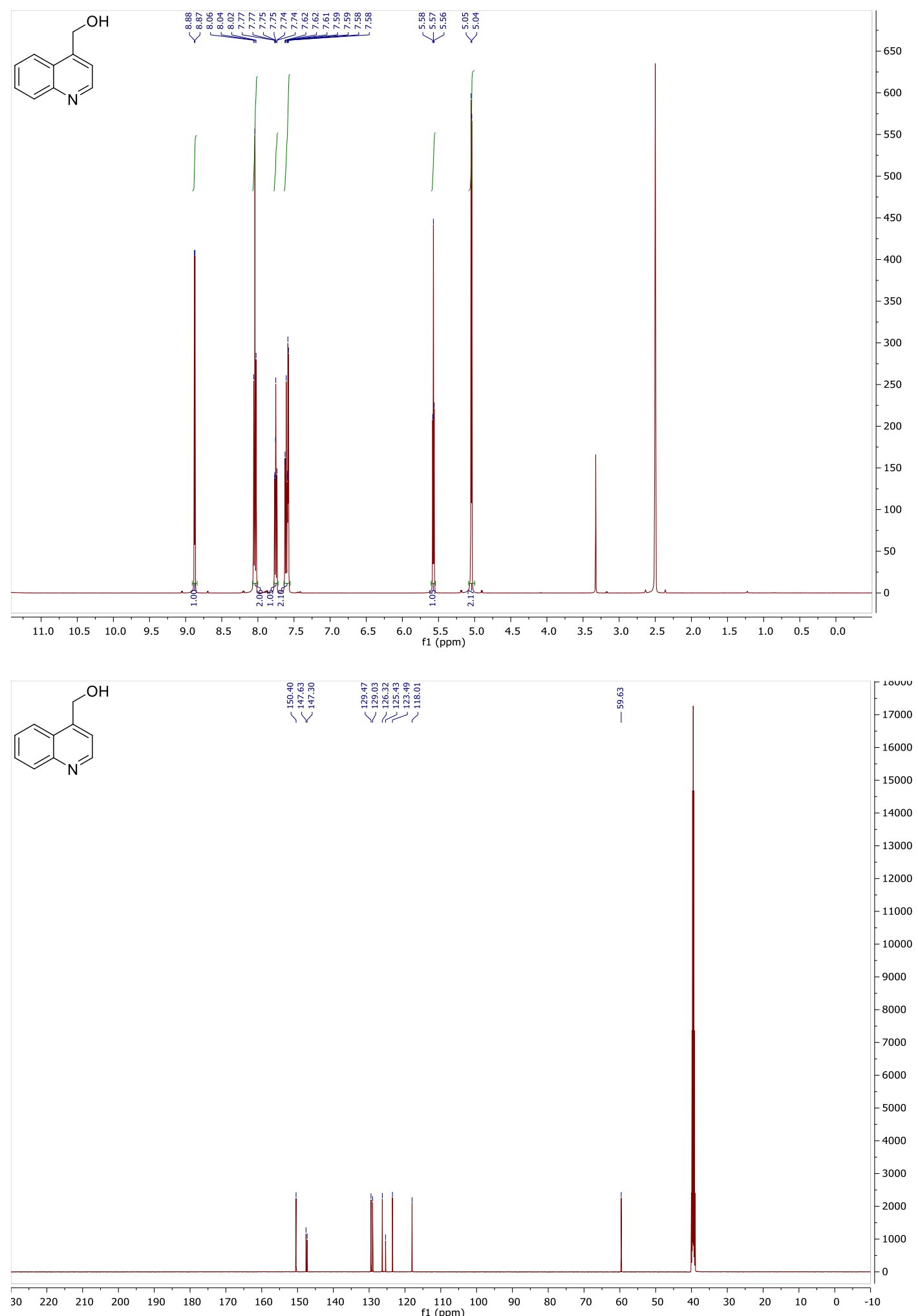
12. ${ }^{1} \mathrm{H}$ and ${ }^{13} \mathrm{C}$ NMR Spectra of Alcohol Oxidation Products
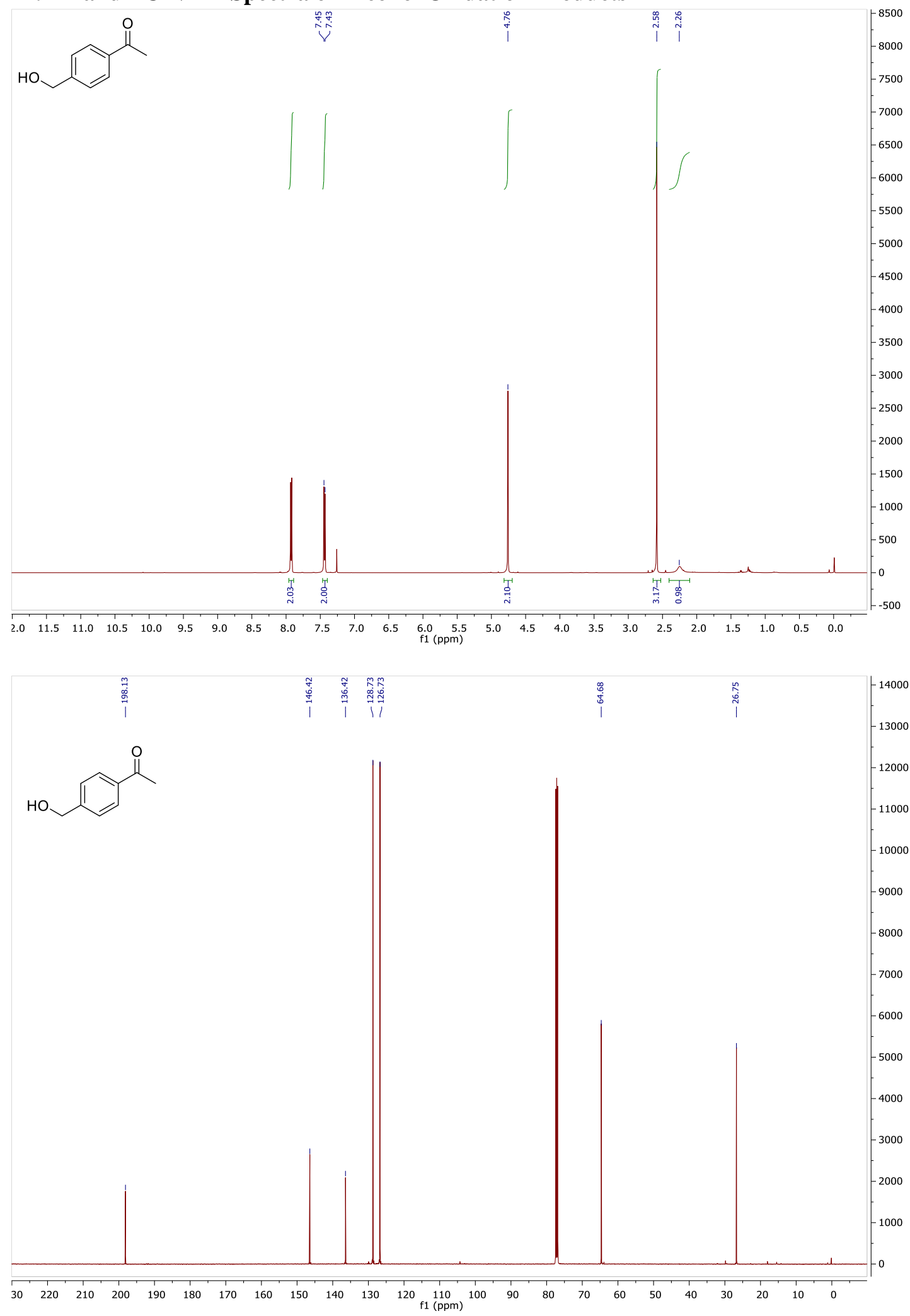

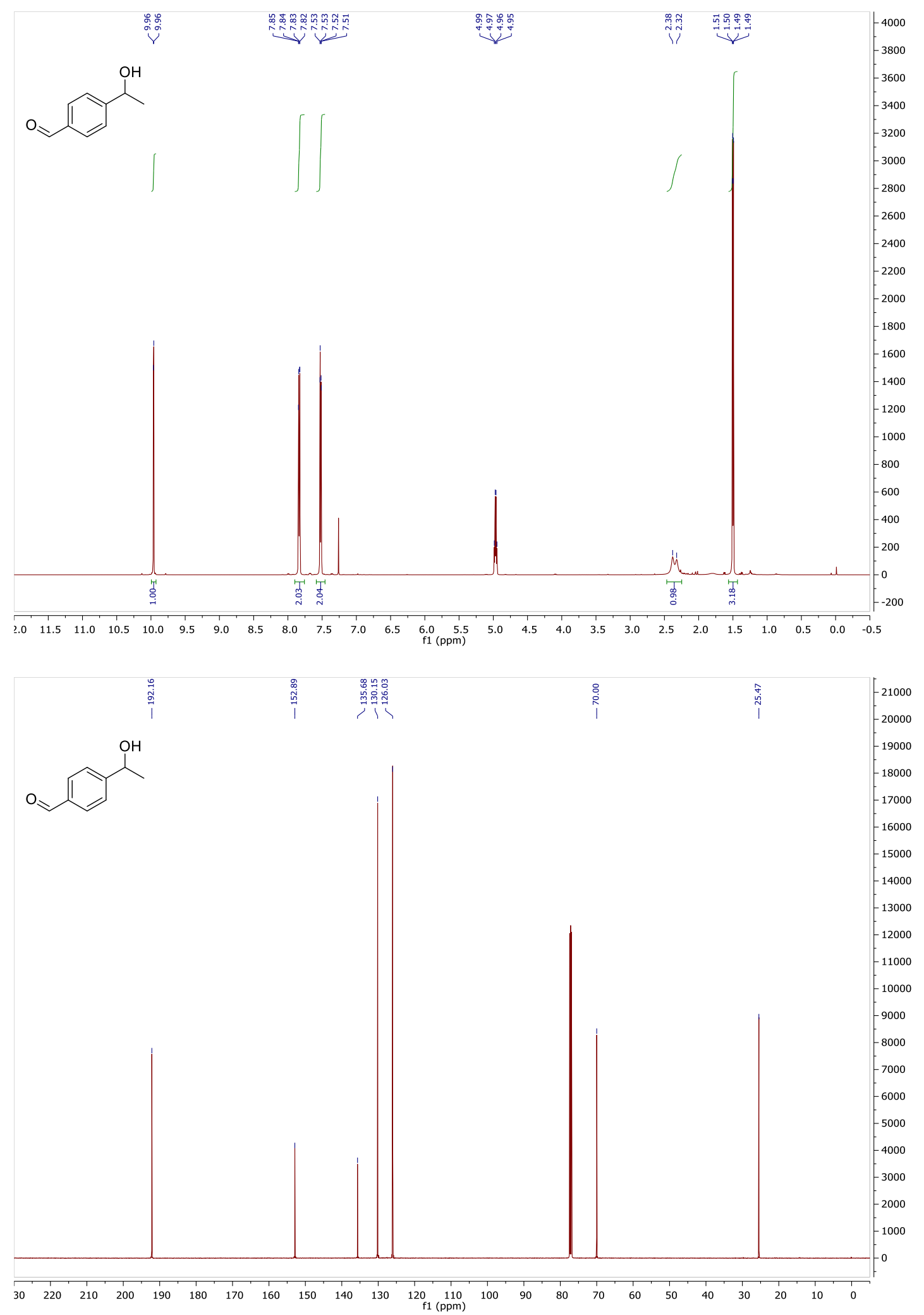

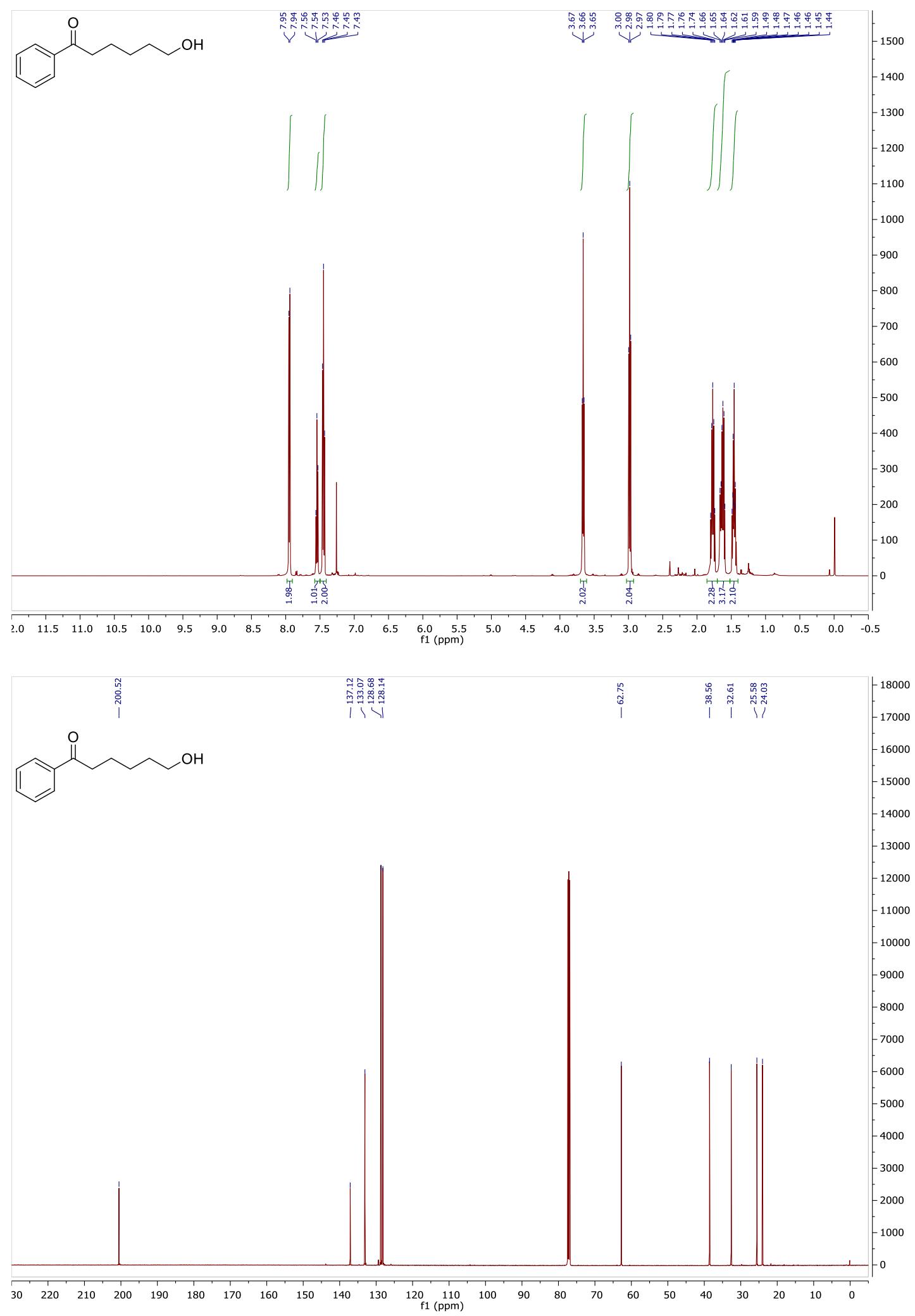

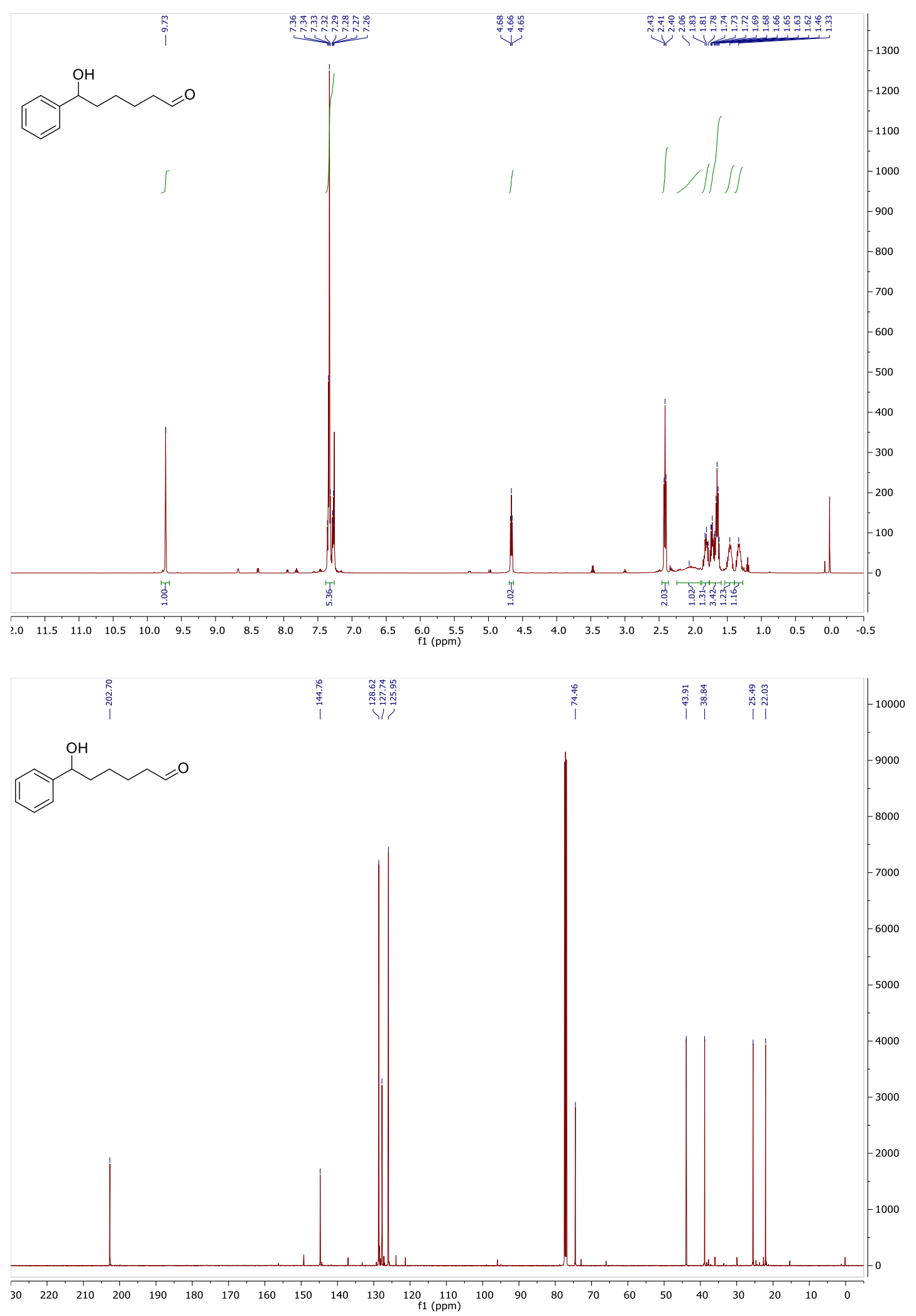

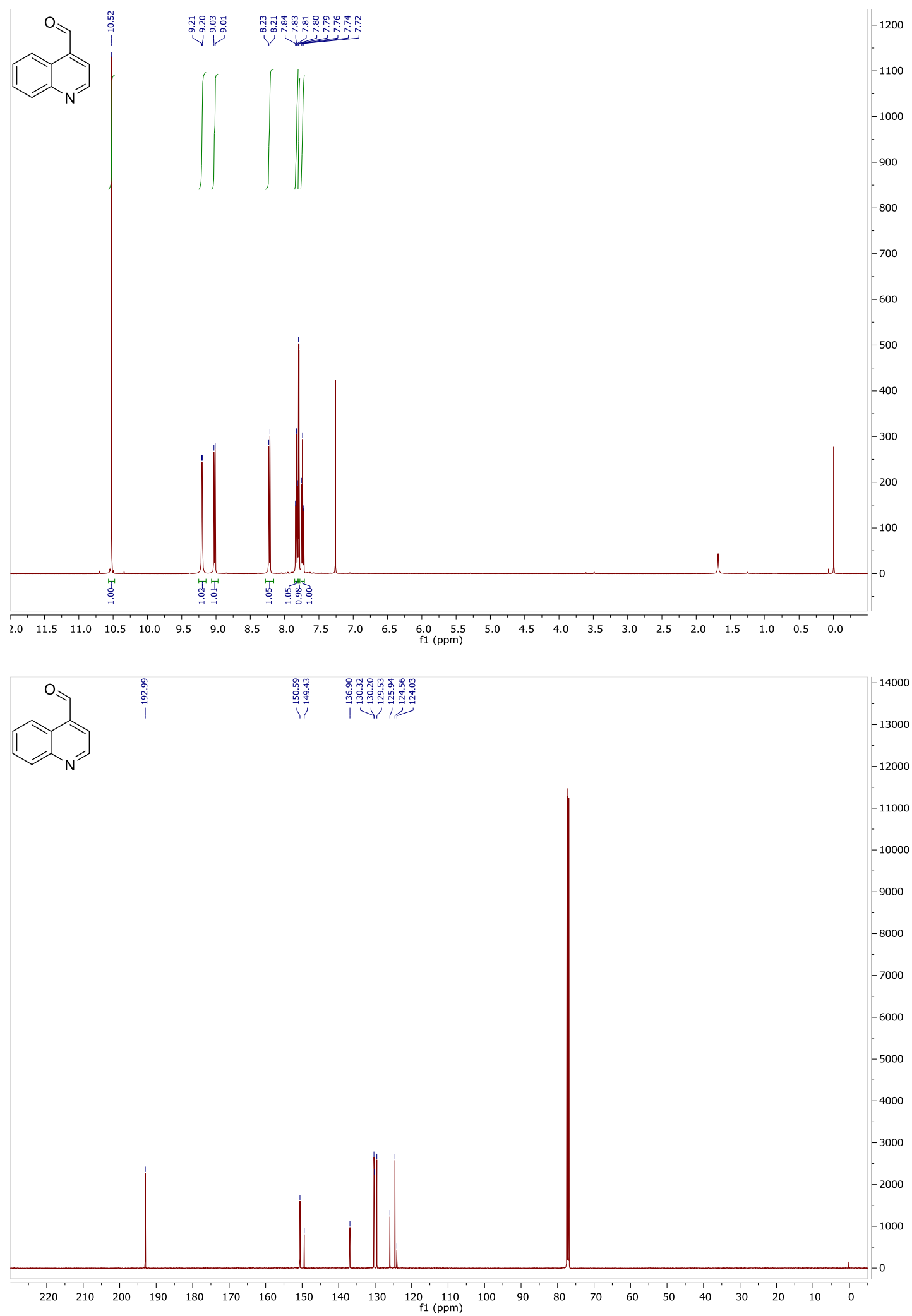


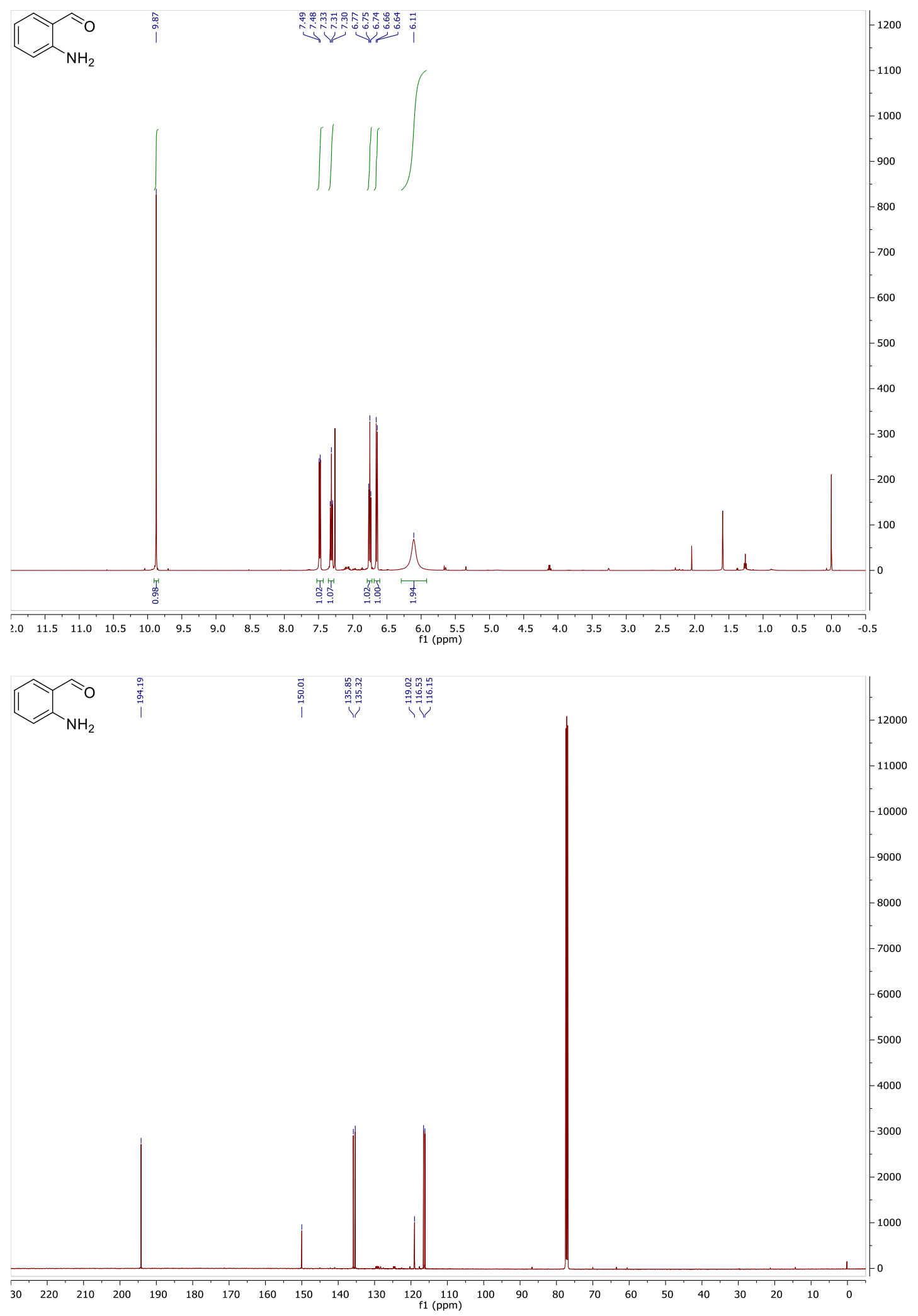




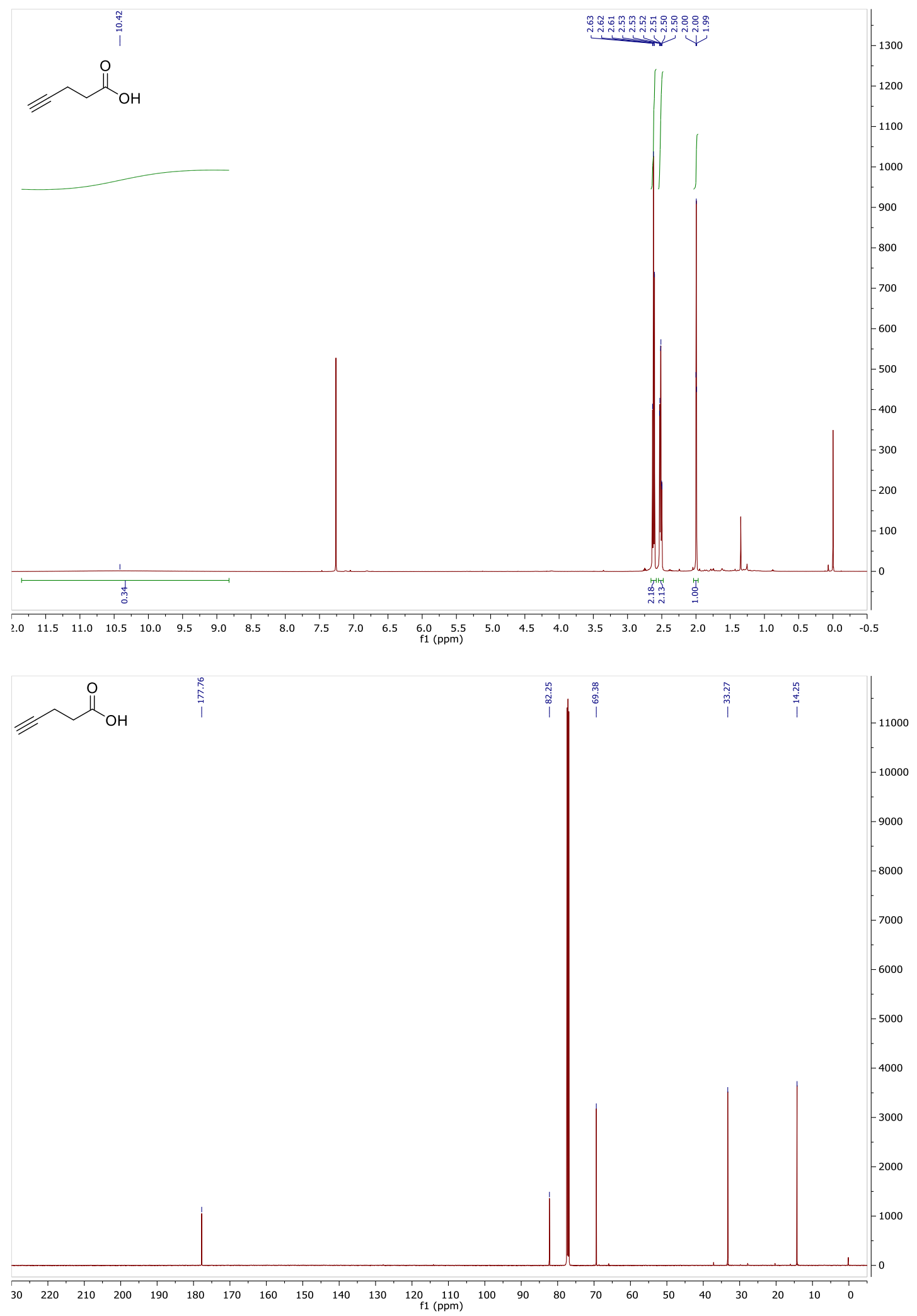




\section{References}

1. Salazar, C. A.; Thompson, B. J.; Knapp, S. M. M.; Myers, S. R.; Stahl, S. S. Multichannel GasUptake/Evolution Reactor for Monitoring Liquid-Phase Chemical Reactions. Rev. Sci. Instrum. 2021, 92, 044103.

2. Rafiee, M.; Miles, K. C.; Stahl, S. S. Electrocatalytic Alcohol Oxidation with TEMPO and Bicyclic Nitroxyl Derivatives: Driving Force Trumps Steric Effects. J. Am. Chem. Soc. 2015, 137, 1475114757.

3. Hoover, J. M.; Ryland, B. L.; Stahl, S. S. Mechanism of Copper(I)/TEMPO-Catalyzed Aerobic Alcohol Oxidation. J. Am. Chem. Soc. 2013, 135, 2357-2367.

4. Hoover, J. M.; Stahl, S. S. Highly Practical Copper(I)/TEMPO Catalyst System for Chemoselective Aerobic Oxidation of Primary Alcohols. J. Am. Chem. Soc. 2011, 133, 16901-16910.

5. Nacsa, E. D; MacMillan, D. W. C. Spin-Center Shift-Enabled Direct Enantioselective $\alpha$-Benzylation of Aldehydes with Alcohols. J. Am. Chem. Soc. 2018, 140, 3322-3330.

6. Wang, L.; Shang, S.; Li, G.; Ren, L.; Lv, Y.; Gao, S. Iron/ABNO-Catalyzed Aerobic Oxidation of Alcohols to Aldehydes and Ketones under Ambient Atmosphere. J. Org. Chem. 2016, 81, 2189-2193.

7. Lauber, M. B.; Stahl, S. S. Efficient Aerobic Oxidation of Secondary Alcohols at Ambient Temperature with an ABNO/NOx Catalyst System. ACS Catal. 2013, 3, 2612-2616.

8. Jiang, X.; Zhang, J.; Ma, S. Iron Catalysis for Room-Temperature Aerobic Oxidation of Alcohols to Carboxylic Acids. J. Am. Chem. Soc. 2016, 138, 8344-8347.

9. Lagerblom, K.; Wrigstedt, P.; Keskiväli, J.; Parviainen, A.; Repo, T. Iron-Catalysed Selective Aerobic Oxidation of Alcohols to Carbonyl and Carboxylic Compounds. ChemPlusChem 2016, 81, 11601165 .

10. Zhai, D.; Ma, S. Copper Catalysis for Highly Selective Aerobic Oxidation of Alcohols to Aldehydes/Ketones. Org. Chem. Front. 2019, 6, 3101-3106.

11. Ma, X.; Li, Z.; Liu, F.; Cao, S.; Rao, H. Tetra- $n$-butylammonium Bromide: A Simple but Effective Organocatalyst for Alcohol Oxidation under Mild Conditions. Adv. Synth. Catal. 2014, 356, 17411746.

12. Lipshutz, B. H.; Hageman, M.; Fennewald, J. C.; Lindstadt, R.; Slack, E.; Voigtritter, K. Slective Oxidations of Activated Alcohols in Water at Room Temperature. Chem. Commun. 2014, 50, 11378 11381.

13. Komagawa, H.; Maejima, Y.; Nagano, T. Sodium Bromide-Catalyzed Oxidation of Secondary Alcohols Using Aqueous Hydrogen Peroxide as Terminal Oxidant. Synlett 2016, 27, 789-793.

14. Gao, X.; Han, S.; Xheng, M.; Liang, A.; Li, J.; Zou, D.; Wu, Y.; Wu, Y. Transition-Metal-Free Oxidation of Benzylic C-H Bonds of Six-Membered N-Heteroaromatic Compounds. J. Org. Chem. 2019, 84, 4040-4049. 